\title{
Bromeliaceae and Orchidaceae on rocky outcrops in the Agreste Mesoregion of the Paraíba State, Brazil ${ }^{1}$
}

\author{
Thaynara de Sousa Silva², Leonardo Pessoa Felix ${ }^{3}$ and José Iranildo Miranda de Melo²,4
}

Received: 11.09.2014; accepted: 12.03.2015

\begin{abstract}
Bromeliaceae and Orchidaceae on rocky outcrops in the Agreste Mesoregion of Paraíba State, Brazil). The present study consists of the floristics-taxonomic survey of Bromeliaceae and Orchidaceae on rocky outcrops located at an Atlantic Forest-Caatinga transition area in Paraíba State, northeast of Brazil, in order to provide data for the implementation of the biota conservation's policies, especially of the flora associated to rocky environments of Paraíba State, given that the taxonomic studies focusing on such families in this state are still incipient. During the study, ten species in six genera of Bromeliaceae and six species in five genera of Orchidaceae were recorded. The treatment includes keys for recognition of the species of families, morphological descriptions, illustrations, geographic distribution data, and comments on the phenology of the species.
\end{abstract}

Keywords: Brazilian flora, semiarid, monocotyledons

RESUMEN - (Bromeliaceae y Orchidaceae en afloramientos rocosos de la Mesoregión Agreste del Estado de Paraíba, Brasil). El presente trabajo consiste en el estudio florístico y taxonómico de Bromeliaceae y Orchidaceae en afloramientos rocosos ubicados en un área de transición de la Foresta Atlántica-Caatinga del Estado de Paraíba, nordeste de Brasil, con el fin de proporcionar datos para la aplicación de las políticas de conservación de la biota, especialmente de la flora asociada a ambientes rocosos del Estado de Paraíba, dado que son aún incipientes los estudios taxonómicos que se centran en estas familias en el Estado. Durante el estudio fueron registradas diez especies en seis géneros de Bromeliaceae y seis especies en cinco géneros de Orchidaceae. El tratamiento incluye claves para el reconocimiento de las especies de ambas familias, descripciones morfológicas, ilustraciones, datos de distribución geográfica, y comentarios sobre la fenología de las especies. Palabras clave: Flora brasileña, monocotiledóneas, semiárido

\section{Introduction}

The Agreste Mesoregion of the Paraíba State, area of semiarid climate is notable for having a meaningful set of granite and gneissic rocky outcrops that abruptly develope above the surrounding landscape (Sarthou et al. 2001, Porembski 2007, Araújo et al. 2008). These rocky outcrops, usually of Pre-Cambrian origin, present distinctive edaphic and microclimatic conditions, such as drought stress, insolation and high temperatures (Barthlott et al. 1993, Porembski 2007, Araújo et al. 2008). They are distributed throughout the world, especially in tropical regions, being particularly common in the Northeast region of Brazil (Porembski et al. 1998, Sarthou et al. 2003, Pitrez 2006).
Bromeliaceae Juss. and Orchidaceae Juss. are common families on rocky outcrops and considered as characteristic groups in the vegetation of these environments (Barthlott et al. 1993, Meirelles et al. 1999, Sarthou et al. 2003, Porembski 2007, Pessoa \& Alves 2014). Both have their main diversity centers in tropical areas, being composed, respectively, of ca. 3,200 species in 58 genera (Luther 2008) and 24,500 species in 785 genera (Dressler 2005, Pessoa et al. 2011). It is estimated that ca. 1,300 species of bromeliads and 2,450 of orchids occur in Brazil; of which 412 and 606 species, respectively, are reported from the northeast region (Barros et al. 2014, Forzza et al. 2014).

Despite the substantial representation, floristic inventories and taxonomic treatments covering

1. Trabalho de Conclusão de Curso da primeira Autora

2. Universidade Estadual da Paraíba, Centro de Ciências Biológicas e da Saúde, Departamento de Biologia, Campus I, Rua das Baraúnas, 351, 58429-500 Campina Grande, Paraíba, Brazil

3. Universidade Federal da Paraíba, Campus II, Rodovia PB-079, 58397-000 Areia, Paraíba, Brazil

4. Autor para correspondência: tournefort@gmail.com 
Bromeliaceae and Orchidaceae in bedrock settled in the Paraíba State are still missing. Thus, given the need to improve the knowledge of the richness of monocotyledons as well as to protect their representatives and respective areas this work presents the floristics-taxonomic study of Bromeliaceae and Orchidaceae on two rocky outcrops sets situated on Paraíba State, northeast from Brazil.

\section{Material and methods}

Study Area - The sampled area (figure 1) in this study includes two rocky outcrops (figure $2 a-b$ ) of the cities of Pocinhos and Puxinanã, in the Campina Grande Microregion, Agreste Mesoregion, Paraíba State, Brazilian northeast. Both cities are identified, from a geomorphologic point of view, as part of the Borborema Plateau (AESA 2014). Pocinhos $\left(07^{\circ} 0514\right.$ 'S - 36 $\left.6^{\circ} 0356^{\prime} \mathrm{W}\right)$ and Puxinanã $\left(07^{\circ} 08^{\prime} 62.1 \mathrm{~S}\right.$, $35^{\circ} 58^{\prime} 31.4 \mathrm{~W}$ ) are located at a varying altitude of 600 to $700 \mathrm{~m}$. Pocinhos with annual maximum temperature of $30^{\circ} \mathrm{C}$ and minimum of $21^{\circ} \mathrm{C}$, and highest precipitation period in March and June (Andrade et al. 2007) and Puxinanã with maximum registered temperature of $28^{\circ} \mathrm{C}$ and minimum of $16^{\circ} \mathrm{C}$, with precipitation periods from January, March to July, and August (Tölke et al. 2011).

In general, Paraíba's Agreste Mesoregion is phytophysiognomic characterized as an ecologic transitional area between montane forest (Caatinga enclaves moist forests) and the deciduous spiny vegetation (Caatinga), (having areas with different humidity and dry conditions) presenting parts almost as humid as the coast and others as dry as the backcountry (Pereira et al. 2002). Consequently, according to Köppen-Geiger's classification (Peel et al. 2007), the climate is hot semiarid (Bsh, with average annual rainfall of ca. $700 \mathrm{~mm}$ and severe water scarcity (Brasil 1972, Pereira et al. 2002).

Field and laboratory procedures - The samples in reproductive state were collected through fortnightly excursions between December/2012 and December/2013. All specimens were deposited at the Herbarium Manuel de Arruda Câmara (ACAM). Specimens housed at EAN (Jayme Coelho de Morais) and JPB (Lauro Pires Xavier) were also analyzed (both herbaria linked to the Federal University of Paraíba (UFPB)). The herbaria acronyms follow Thiers (2014).

The taxonomic descriptions were based on specimens collected by the authors and those analyzed at herbaria collections. Complementary data for some species were obtained from the following literature: Smith \& Downs (1974, 1979), Pabst \& Dungs (1975, 1977), Dressler (1993), Sousa \& Wanderley (2000), Forzza (2005), Pontes (2005), Pontes \& Agra (2006), Azevedo \& Van den Berg (2007), Cunha \& Forzza (2007), Monteiro \& Forzza (2008), Saddi (2008), Alves et al. (2009), Coffani-Nunes et al. (2010) Gonçalves \& Lorenzi (2011), Pessoa \& Alves (2011, 2012) and Luiz-Santos \& Wanderley (2012).

\section{Results and Discussion}

\section{Bromeliaceae A.Juss., Gen. P1.: 49-50. 1789.}

In the study area were recorded ten species distributed in six genera.

According to Forzza et al. (2014), Paraíba's flora covers $12 \%$ of a total of 412 reported species for the northeast region; however, there are still few studies addressing the taxonomy and distribution of the Bromeliaceae species in Paraíba State. Despite this, works conducted by Pitrez (2006), Porto et al. (2008) and Tölke et al. (2011), in addition to this study, reflect this family's representativeness in the State's rocky outcrops. Of the 10 species of Bromeliaceae recorded in the study area, seven were found in Pocinhos and six in Puxinanã; being the species Orthophytum disjunctum L.B. Sm. and Tillandsia recurvata (L.) L. common to both sets of rocky outcrops studied (table 1).

Key to the Bromeliaceae species from rocky outcrops of the cities of Pocinhos and Puxinanã

1. Capsule fruit; superior ovary

2.Rupicolous plants; procumbent stem; spiny leaves, rosette shaped, forming a tank; welldeveloped scape (0.9-1.5 m length); tiny floral bracts; non-tubular flowers; seeds with winged appendage . Encholirium spectabile

2. Rupicolous or epiphyte plants; non-procumbent stem; spineless, distichous or polystichous leaves, not forming a tank; underdeveloped scape (3-50 cm length); showy floral bracts; tubular flowers; seeds with filiform appendage 
3. Distichous leaves, strongly recurved; scape with 1 bract Tillandsia recurvata

3. Polystichous leaves, erect and slightly recurved; densely bracteate scape

4. Leaves with sheaths indistinct from the blade; exserted stamens Tillandsia polystachia

4. Leaves with sheaths slight to strongly distinct from the blade; stamens included

5. Plants 5-11 cm height, epiphyte; few-flowered inflorescence; yellow flowers, polysepalous calyx; free stamens Tillandsia loliacea

5. Plants 12-22 cm height, rupicolous; multiflora inflorescence; while flowers, calyx with 2 connate sepals and 1 free; epipetalous stamens

Tillandsia tenuifolia

1. Berry fruit; inferior ovary

6. Variegate leaves; raceme inflorescence; reddish corolla Neoglaziovia variegata

6. Non-variegated leaves; panicle shaped inflorescence; white, purple or purplish white corolla

7. Inflorescence in panicle of fascicles; floral bracts of serrated margin Orthophytum disjunctum

7. Inflorescence in simple or spiked panicle; floral bracts of entire margin

8. Glossy leaves; pedicellate flowers; absent petal appendage Bromelia laciniosa

8. Dull leaves; sessile flowers; petal appendages present

9. Spines set largely apart (0.5-3.2 cm length); pendulum inflorescence, subcylindrical, congested spikes, short primary bracts Hohenbergia catingae

9. Spines set close together (0.4-0.5 cm length); erect inflorescence, pyramidal, spaced spikes, and elongated primary bracts Hohenbergia horrida

1. Bromelia laciniosa Mart. ex Schult. \& Schult. f., Syst. veg. 7(2): 1278. 1830. Common name: macambira (Paraíba)

Figure $2 \mathrm{c}$

Rupicolous, ca. $92 \mathrm{~cm}$ height; well-developed stem, procumbent. Leaves 56-70 $\mathrm{cm}$ length, polystichously, rosette shaped, forming a tank, non-variegate, glossy; sheaths 5-7 × 2.3-3 cm, oval, chartaceous, pale, brownish, densely lepidote; blade 45-63.5 × 1.7-2.7 cm, linear, long attenuated, green or greenish red, glossy, spiny margin, 4-8 mm length spines, antrorse, 1.2-2.5 cm length spaced, dark brown, acute apex. Scape ca. $58 \mathrm{~cm}$ length, erect, cylindrical, robust, not exceeding the length of the majority of the leaves, rosy, lepidote; scape bracts 11-30 cm length, lanceolate, non-imbricate, red, densely lepidote, acute apex. Inflorescence ca. $32 \mathrm{~cm}$ length, panicle shaped, simple panicle, inserted in the rosette, erect, cylindrical, rosy, lepidote; floral bracts $2.5-4.5 \mathrm{~cm}$ length, lanceolate, red, densely lepidote, entire margin, acute apex. Flowers 1.2-1.8 cm length, tubular, erect, purplish white, pedicellate, $1.5-2 \mathrm{~cm}$ length pedicel, rosy; sepals $0.8-1 \times 0.4-0.6 \mathrm{~cm}$, concrescent to the pedicel, obovate, stiff, glabrous, acuminated apex; petals 1.1-1.4 × 0.3-0.4 cm, oblong, imbricate in the anthesis, viscid, purplish white, rounded apex, absent petal appendage; epipetalous stamens; anthers ca. $4 \mathrm{~mm}$ length, rimose, basifixed, hyaline; inferior ovary, hypanthium forming a tube; style ca. $7 \mathrm{~mm}$ length, cylindrical; trifid stigma, conduplicate spiral, lobed laminate; numerous ovules. Berry 2.8-3.5 cm length, yellow, ellipsoid, robust; seeds with appendage.

Distribution and habitat: Bromelia laciniosa is an endemic species to Brazilian's northeast (Smith \& Downs 1979, Forzza et al. 2014). Only two Bromelia species occur in Paraíba State, Bromelia karatas L. occurs in the Atlantic Forest and B. laciniosa in Caatinga (Pontes 2005). Morphologically, B. laciniosa differs from $B$. karatas mainly by the presence of the scape. In the study area, B. laciniosa was found under trees and in clearings formed between bushes at the edge of rocky outcrops in the city of Puxinanã.

Phenology: Flowered in March and May, and fruited in May.

Morphologically it is characterized for having glossy leaves, red bracts of scape and densely lepidote, pedicellate flowers with hypanthium forming a tube, purplish white petals and ellipsoid, robust, berry fruit.

The species shows a potential economic value because in the Caatinga it is used for feeding people and their livestock (caprine, ovine and swine); mainly during the long periods of dry weather (Angelim et al. 2007, Lima 2008, Rocha 2010).

Specimens examined: BRAZIL. PARAíBA: Puxinanã, 4-V-2013, T.S. Silva 13 (ACAM); idem, 31-V-2013, T.S. Silva 21 (ACAM); idem, 6-VII-2013, T.S. Silva 29 (ACAM). 
Additional specimen examined: BRAZIL. PARAíBA: Areia,15-XI-1955, J.C. Moraes (EAN1594). Esperança, 1-III-2005, L.P. Felix 10614 (EAN).

2. Encholirium spectabile Mart. ex Schult. \& Schult. f., in Roem. \& Schult., Syst. veg. 7(2): 1233. 1830. Common name: macambira de lajedo (Paraíba) Figure 3 a-1

Rupicolous, ca. 140-270 cm height; welldeveloped stem, procumbent. Leaves $50-90 \mathrm{~cm}$ length, polystichous, rosette shaped, forming a tank, spiny; sheath 3-7 cm length, oval, coriaceous, brownish white; blade $24-75 \times 2.1-4.5 \mathrm{~cm}$, linear lanceolate, light green, pruinose lepidote, spiny margin, ca. $10 \mathrm{~mm}$ spines length, erect or retrorse, dark, 3-4 cm length spaced. Scape 90-150 cm length, well developed, erect, cylindrical, robust, exceeding the rosette, greenish brown, glabrous, bracts through its entire extension; scape bracts 7.5-27.5 cm length, non-imbricate, spaced, vinaceous base, triangular lanceolate, spiny margin, long attenuated apex, lepidote. Inflorescence 80-100 cm length, raceme, extending beyond the rosette, multiflora, congested; 0.6-1.9 cm length floral bracts, tiny, matching or exceeding the pedicels, not exceeding the flowers, triangular lanceolate, recurved, dusky, acute apex. 1.4-2.1 cm length flowers, non-tubular, yellowish, short pedicellate, $0.4-1 \mathrm{~cm}$ length pedicel, green to brown, glabrous; sepals 0.6-1 $\times 0.4-0.7 \mathrm{~cm}$, oval, concrescent to the pedicel, viscid, greenish brown, glabrous, entire margin, membranaceous, retuse apex, vinaceous; petal $1-2 \times 0.6-1 \mathrm{~cm}$, elliptic, non-imbricate in the anthesis, yellowish green, entire margin, hyaline, involute in the apex direction, glabrous, obtuse to slightly retuse apex, vinaceous; 8-32 $\mathrm{mm}$ length stamens, free, yellowish; erect filaments; anthers 6-10 mm length, dorsifixed, rimose, golden yellow; 9-11 mm length ovary, superior, glabrous; style 10-12 mm length, trigonous; trifid stigma, conduplicate spiral, lobed laminate; numerous ovules, arranged in a row. Capsule ca. $2 \mathrm{~cm}$ length, dehiscent; seeds ca. $0.3 \mathrm{~cm}$ length, flat, filiform, with winged appendage.
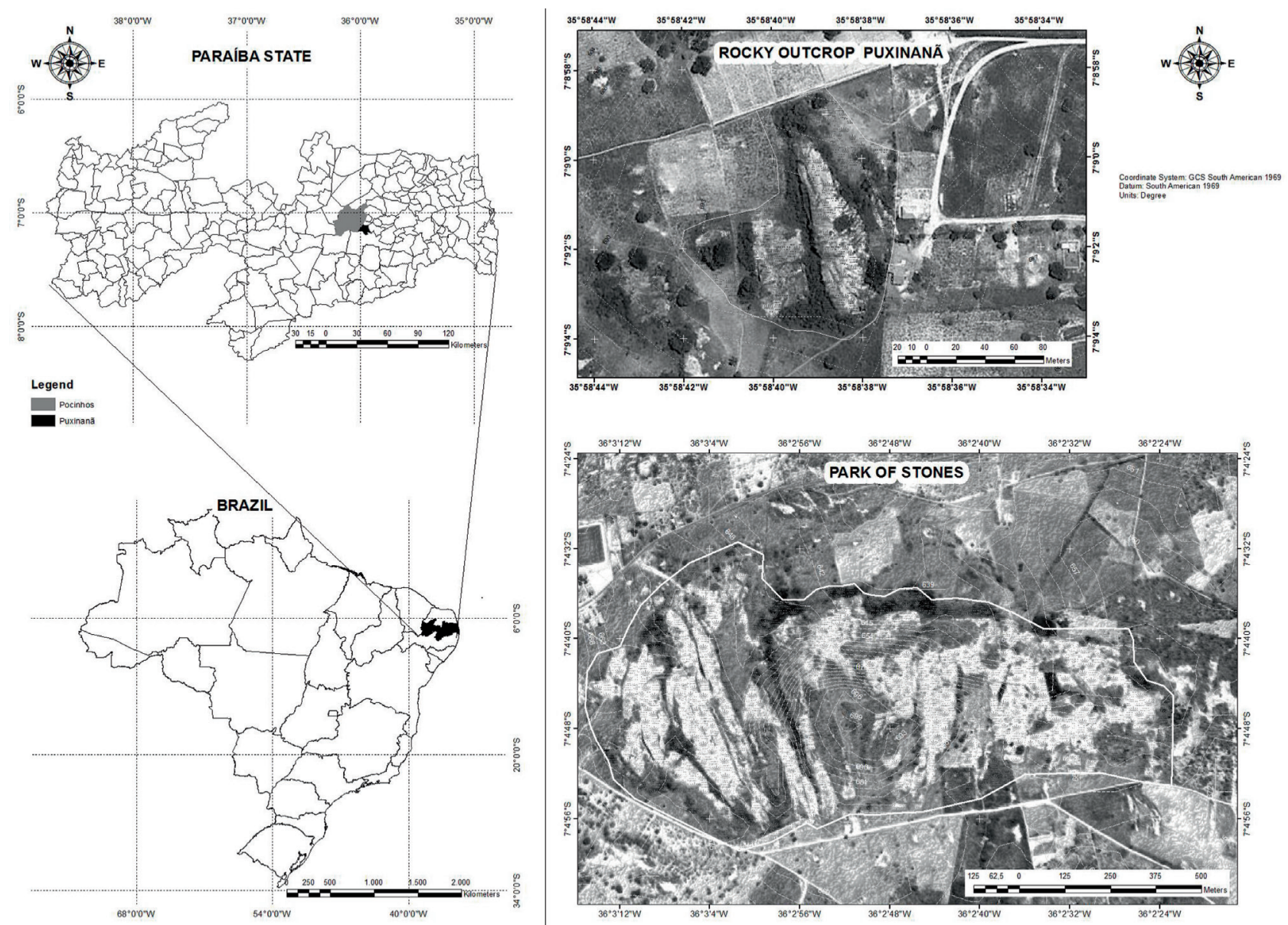

Figure 1. In the first plane (anti-clockwise), the location of the municipalities of Pocinhos and Puxinanã in the Paraíba State, Brazil; in the second and third plane, the location of the studied areas. 
Distribution and habitat: This Encholirium species is notable (stand out) for having the wider and more northern geographic distribution observed in the genera, being frequently found in rocky outcrops of Brazilian's caatinga (Cavallari 2004, Forzza 2005, Alves et al. 2009). In this study, E. spectabile is the most common Bromeliaceae species recorded on the rocky outcrops; and it is usually the main component of the rocky outcrops vegetation island of Pocinhos.

Phenology: Flowered in November and December, and fruited in December.

Forzza (2005) states that E. spectabile is the taxon with the greatest morphologic variability of the genera, showing (displaying) considerable phenotypic plasticity. It is distinguished for having raceme inflorescence with short pedicellate flowers, non-imbricate scape bracts, well-spaced, tiny floral bracts, petals non-imbricate in the anthesis; exserted stamens and styles and lobed laminate stigma.

Specimens examined: BRAZIL. PARAíba: Pocinhos, 12-XII-2012, T.S. Silva 03 (ACAM); idem, 10-VI-2013, T.S. Silva 24 (ACAM); idem, 6-VIII-2013, T.S. Silva 34 (ACAM). Puxinanã, 6-III-2013, T.S. Silva 8 (ACAM).

Additional specimens examined: BRAZIL. PARAíBA: Alagoa do Remígio, 20-X-1946, J.C. Moraes s.n. (EAN 580). Esperança, Lagoa de Pedra, 14-XI-2002, S. Pitrez et al. 463 (EAN).
3. Hohenbergia catingae Ule, Bot. Jahrb. Syst. 42(2-3): 195. 1908

Figures $2 \mathrm{~d}, 4 \mathrm{a}$

Rupicolous, ca. $120 \mathrm{~cm}$ height; well-developed stem, procumbent. Leaves 55-65 cm length, polystichous, rosette shaped, forming a tank, nonvariegate, dull; 22-24 × 9-11 cm sheaths, oblong, coriaceous, light brown; blade 30-50 × 2.2-5 cm, lanceolate, coriaceous, dull, green, strongly nerved, spiny margin, 3-4 $\mathrm{mm}$ spines length, antrorse, dark brown, set largely apart (0.5-3.2 cm length), rostral apex, pungent. Scape 30-50 cm length, erect, cylindrical, robust, exceeding the leaves, reddish, strongly flaky; scape bracts $1.6-2.8 \mathrm{~cm}$ length, oblong lanceolate, non-imbricate, amplectant, ferruginous, acuminated apex. Inflorescence ca. $24 \mathrm{~cm}$ length, panicle shaped, spiked panicle, subcylindrical, pendulum, tripinnate spikes, dense, downy, sessile pinnas, well developed; primary bracts 1.4-1.7 $\times 0.5-0.7 \mathrm{~cm}$, short, latent, triangular, pungent apex; 0.7-1 × 0.5-0.7 cm floral bracts, navicular, long attenuated, involucral, rosy cream, winged, entire margin, acuminated apex. Flowers ca. $1.4 \mathrm{~cm}$ length, sessile, tubular, purplish, present (with) petal appendage; sepals 0.6-0.7 $\times 0.4-0.5 \mathrm{~cm}$, free among them, oval, mucronated apex, mucro ca. $0.5 \mathrm{~mm}$ length, imbricate, carinate, rigid, membranaceous and translucent wings; petals $0.8-0.9 \times 0.1-0.2 \mathrm{~cm}$,

Table 1. Bromeliaceae and Orchidaceae species registered in this study for each municipality, Paraíba State, Brazil.

\begin{tabular}{lcc}
\hline Species & Pocinhos & Puxinanã \\
\hline Bromelia laciniosa Mart. ex Schult. \& Schult. & & $\mathrm{X}$ \\
Encholirium spectabile Mart. ex Schult. \& Schult. & $\mathrm{X}$ & $\mathrm{X}$ \\
Hohenbergia catingae Ule & & $\mathrm{X}$ \\
Hohenbergia horrida Harms & $\mathrm{X}$ & \\
Neoglaziovia variegata (Arruda) Mez & $\mathrm{X}$ & \\
Orthophytum disjunctum L. B. Sm. & $\mathrm{X}$ & $\mathrm{X}$ \\
Tillandsia loliacea Mart. ex Schult. \& Schult. & $\mathrm{X}$ & \\
Tillandsia polystachia (L.) L. & $\mathrm{X}$ & \\
Tillandsia recurvata (L.) L. & $\mathrm{X}$ & $\mathrm{X}$ \\
Tillandsia tenuifolia L. & & $\mathrm{X}$ \\
Acianthera ochreata (Lindl.) Pridgeon \& M. W. Chase & $\mathrm{X}$ & $\mathrm{X}$ \\
Brassavola tuberculata Hook & & $\mathrm{X}$ \\
Cyrtopodium flavum Link \& Otto ex Rchb. & $\mathrm{X}$ & \\
Cyrtopodium holstii L. C. Menezes & $\mathrm{X}$ & $\mathrm{X}$ \\
Habenaria obtusa Lindl. & $\mathrm{X}$ & \\
Prescottia plantaginifolia Lindl. & $\mathrm{X}$ & \\
\end{tabular}


free among them, patents in the anthesis, spatular, purple, obtuse apex, petal appendage ca. $1 \mathrm{~mm}$ length, spatular, serrated apex, connate close to the petal base; stamens included, free or epipetalous filaments, inserted between petal appendages; linear anthers, dorsifixed; ovary inferior, downy; conduplicate spiral stigma, caudate ovules. Fruits and seed not observed.

Distribution and habitat: Hohenbergia catingae was reported to Paraíba and Bahia States by Smith \& Downs (1979). In the studied area, it is found in the rock outcrop of Puxinanã, forming an island along with the species of the Cactaceae, Euphorbiaceae and Marcgraviaceae families.

Phenology: Flowered in May and July.

This species can be distinguished from Hohenbergia horrida Harms by having opaque and green leaves with well developed spines, more widely spaced, and inflorescence pendant, subcillindrical, robust, with primary bracts short (1.4-1.7 cm length) in each spike (Smith \& Downs 1979).

Specimens examined. BRAZIL. Paraíba: Puxinanã, 4-V-2013, T.S. Silva 16 (ACAM); idem, 31-V-2013, T.S. Silva 23 (ACAM); idem, 6-VII-2013, T.S. Silva 31 (ACAM).

Additional specimen examined. BRAZIL. ParaíBA: Esperança, 20-VII-2005, R. Pontes et al. 331 (JPB).

4. Hohenbergia horrida Harms, Notizbl. Königl. Bot. Gart. Berlin 12: 525. 1935. Common name: caroá (Paraíba)

Figures 2 e-f, 4 b-c

Rupicolous, 100-150 cm height; well developed stem, procumbent. Leaves 45-70 cm length, polystichously arranged in rosette, forming tank, never variegated, opaque; sheath 21.5-23 ×9-11 cm, oblong, coriaceous, dark vinaceous, lepidota; blade 35-45 × 2-4 cm, linear-lanceolate, strongly ribbed, green-red, cinerea, ribbed, margin aculeate, spines 1.5-3 $\mathrm{mm}$ length, retrorse, dark brown, glabrous, closely spaced (0.4-0.5 cm length), apex rostrate, poignant. Scape 40-100 cm length, erect, cylindrical, robust, exceeding the leaves, reddish, densely flaky; bracts of the scape $4-12.5 \mathrm{~cm}$, not imbricated, ampletive, oblong-lanceolate, chartaceous, paleaceous, lepidote, poignant apex. Inflorescence 30-67 cm length, raceme, panicle of spikes, erect, pyramidal, lanuginosous, tripinnate, spaced, sessile pinnae, undeveloped; primary bracts 2-10 $\times 0.5-3.5 \mathrm{~cm}$, elongated, subimplied, lanceolate, pungent apex; floral bracts 1-1.5 × 0.5-0.6 cm, oval, reddish, winged, margin entire, long-mucronate apex. Flowers ca. $1.2 \mathrm{~cm}$ length, sessile, tubular, purplish; sepals ca. $0.8 \times 0.4 \mathrm{~cm}$, free from each other, oval, imbricate, keeled, margin with membranous wings, apex mucronate, mucro ca. $1 \mathrm{~mm}$ length; petals 1 -ca. $1.2 \times 0.2 \mathrm{~cm}$, spatulate, purple, free from each other, apex obtuse, patent at anthesis, petal appendages ca. $1 \mathrm{~mm}$ length, spatulate, apex serrated, connates near the base of the petal; stamens included, compressed, the internal series ca. $5 \mathrm{~mm}$ length with free filaments by ca. $2 \mathrm{~mm}$ length, inserted between petal appendages, those of outer series ca. $9 \mathrm{~mm}$ length, fillets hyaline; anthers 9-11 mm length, linear; inferior ovary, lanuginous; style ca. $8 \mathrm{~mm}$ length, cylindrical; stigma spiral-conduplicate; ovules ca. $0.6 \mathrm{~mm}$ length, ca. 7 per locule, caudate. Fruits and seeds not observed.

Distribution and habitat: Hohenbergia horrida is endemic to Northeast Brazil; and recorded to the states of Paraíba and Pernambuco (Smith \& Downs 1979, Forzza et al. 2014). In the study area it was found forming extensive outcrop vegetation islands in the municipality of Pocinhos.

Phenology: Found flowered in February.

Initially, this species was reported as one of five varieties of Hohenbergia catingae (Smith \& Downs 1979). However, it is currently considered as Hohenbergia horrida (Forzza et al. 2014). It can be differentiated from Hohenbergia catingae by presenting reddish-green leaves with spines very close to each other, inflorescence pyramidal, erect with primary bracts elongated $(2-10 \mathrm{~cm}$ length) and floral bracts with long-mucronate apex.

Specimens examined: BRAZIL. ParaíBA: Pocinhos, 21-II-2013, T.S. Silva 6 (ACAM); idem, 1-VII-2013, T.S. Silva 26 (ACAM); idem, 15-XI-2013, T.S. Silva 38 (ACAM).

Additional specimen examined: BRAZIL. BAHIA: Jacobina, 16-VI-1999, L.P. Felix 4332 (EAN).

5. Neoglaziovia variegata (Arruda) Mez, Fl. Bras. 3(3): 427, pl. 80, f. 1. 1894.

Rupicolous, ca. $100 \mathrm{~cm}$ height; inconspicuous stem. Polystichously leaves, paucifoleous, erect to slightly recurved, viscid, variegated, lepidote; sheath 5-7 $\times$ 2.5-3.5 cm, coriaceous, white-brownish, lepidota; blade $42-115 \times 1.5-2 \mathrm{~cm}$, linear, revolute 

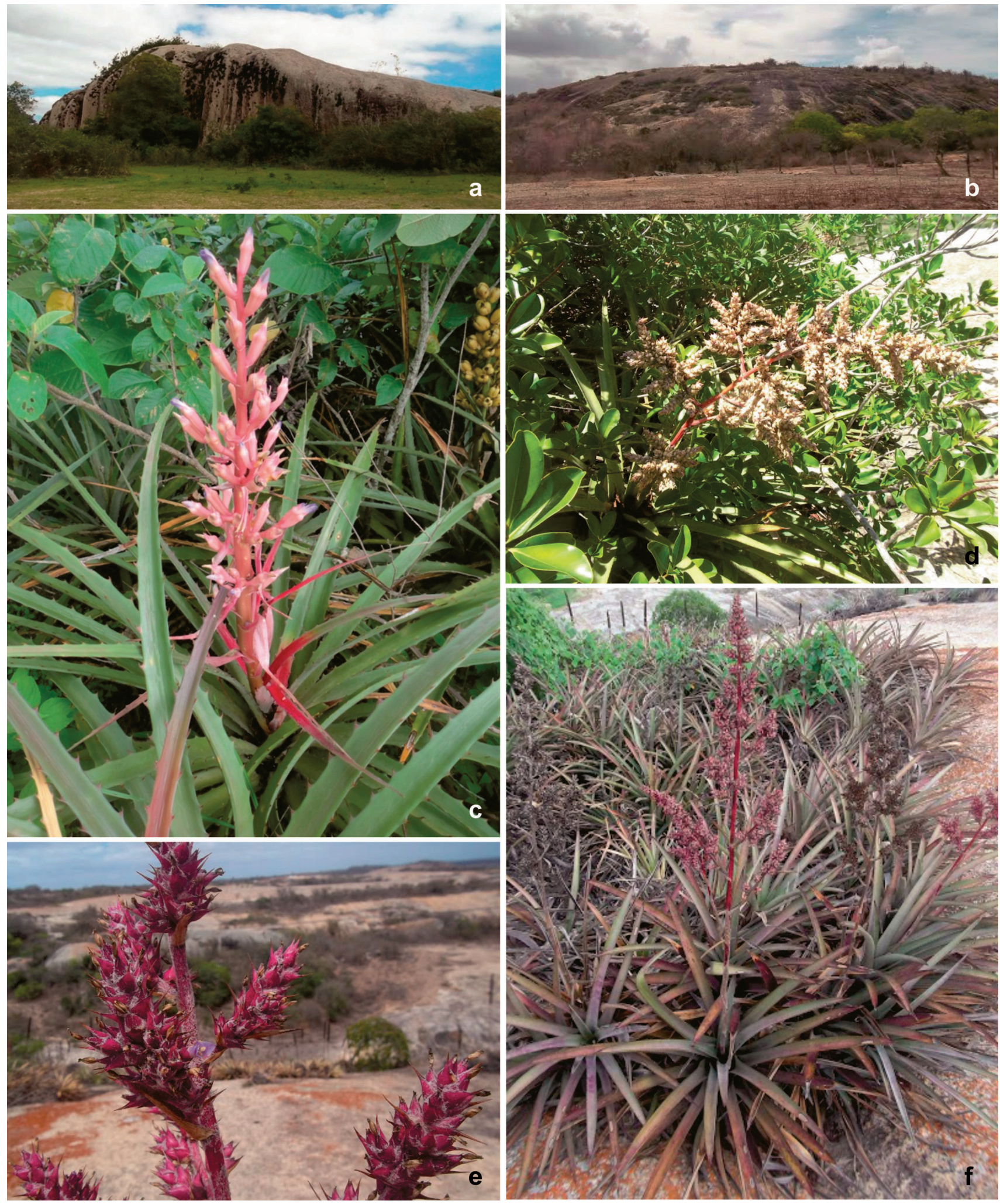

Figure 2. a-b. Outcrops studied. a. rocky outcrop of the municipality of Puxinanã. b. rocky outcrop of the municipality of Pocinhos. c-d. Bromeliaceae species in Puxinanã rocky outcrop. c. Bromelia laciniosa. d. Hohenbergia catingae. e-f. Hohenbergia horrida in Pocinhos. e. Inflorescence. f. Habitat. 
margin, green, variegated parallel of gray, more evident blemishes on the abaxial surface, aculeate, spines 3-4 mm length, antrorse, spaced 0.8-4.5 cm, dark brown, lepidote, apex rostrate. Scape 50-80 cm length, erect, cylindrical, not robust, not exceeding the leaves, reddish, flaky base; bracts of the scape $2.5-10 \mathrm{~cm}$, ampletive, linear-lanceolate, long-attenuated apex, rostrate, chartaceous, lepidote, aculeate margin, miniature spines. Inflorescence $22.5-38 \mathrm{~cm}$ length, racemous, lax, erect; floral bracts $0.4-2.7 \mathrm{~cm}$ length, linear-lanceolate, acute apex, flaky. Flowers $1.5-2.5 \mathrm{~cm}$ length, alternate, reddish, pedicellate, pedicel ca. $0.4 \mathrm{~cm}$ length; sepals ca. $0.6 \times 0.4 \mathrm{~cm}$, free, oval, viscid, membranous margin, apex acute; petals 0.9-1.8 $\times$ 0.3-0.4 cm, elliptic-oval, reddish, margin membranous, hyaline, apex retuso, revolute; stamens ca. $6 \mathrm{~mm}$ length, included, free; anthers ca. $4 \mathrm{~mm}$ length, dorsifixed, yellow; ovary ca. $5 \mathrm{~mm}$ length, inferior, obovate; style ca. $5 \mathrm{~mm}$ length, cylindrical; coiled stigma, trifid, laminar lobes; numerous ovules, oboval. Berry 1-2 cm length; farinose; seeds without appendages.

Distribution and habitat: Neoglaziovia variegata is endemic to Brazil and distributed in the Caatinga of northeastern region and the State of Minas Gerais (Smith \& Downs 1979, Forzza et al. 2014). It can be found from the sub-grove of tree caatingas to open environments, in compact and thin soils; being common in crevices of rocky outcrops (Alves et al. 2009). In the study area, it is found forming populations of few individuals under bushes, in the plateau regions in the outcrop of municipality Pocinhos.

Phenology: Collected with flowers in May and fruits in May and October.

It can be easily distinguished from the other species of this study by its medium size, with variegated leaves and lax racemose inflorescence with red flowers short pedicellate.

Specimens examined: BRAZIL. Paraíba: Pocinhos, 8-V-2013, T.S. Silva 19 (ACAM); idem, 31-XI-2013, T.S. Silva 40 (ACAM).

Additional specimens examined: BRAZIL. PARAíBA: Areia, 15-XI-1955, J.C. Moraes s.n. (EAN 1591). Pedra Lavrada, Serra da Flecha, 30-IV-2007, P.C. Gadelha-Neto et al. 1689 (JPB). São João do Cariri, Fazenda Santana, 18-IX-1997, R.G. Luna 11 (JPB). Pernambuco: Mirandiba, 11-II-2009, K. Pinheiro 1306 (JPB).
6. Orthophytum disjunctum L.B. Sm., Smithsonian Misc. Collect. 126(1): 33, 180, f. 85. 1955. Figure 4 d-g

Rupicolous, 22-50 cm height; inconspicuous stem. Leaves 7.5-13.7 cm length, distichous, patent, recurved, coriaceus, never variegated, lepidote; sheath $0.7-2 \times 1.2-2.3 \mathrm{~cm}$, chartaceous, white; blade 1-1.9 × 8.5-12.5 cm, triangular-lanceolate, dark brown, abaxial face dense lepidote, aculeate margin, spines $0.2-0.3 \mathrm{~cm}$ length, patents, spaced 0.1-0.5 cm length, light brown, long-attenuated apex. Scape 16-42 cm length, cylindrical, erect, greenish, densely flaky; bracts of the scape 4.2-14 $\times 0.9-1.6 \mathrm{~cm}$, triangular-lanceolate, ampletive, chartaceous, serrate margins, long-attenuated apex, lepidote. Inflorescence 4-11 cm length, raceme, panicle of fascicles, exceeding the leaf rosette, flaky; primary bracts 2-7 cm length, similar to the bracts of the scape; floral bracts 1-2 × 0.4-1 cm, oval-lanceolate, viscid, green cinereum, lepidote, serrated margin, apex mucronate, mucron 0.1-0.2 cm length. Flowers 1.3-1.8 cm length, sessile, tubular, erect, white, petal appendices present; sepals $0.9-1.1 \times 0.3-0.5 \mathrm{~cm}$, free, triangular, keeled, symmetrical or slightly asymmetrical, squamose, hyaline margin, apex mucronate, mucro ca. $1 \mathrm{~mm}$ length; petals 1.3-1.5 × 0.2-0.3 cm, free, spatulate, white, apex obtuse; petal appendages ca. $1 \mathrm{~mm}$ length, fimbriate, connate ca. $4 \mathrm{~mm}$ length from the base of the petals; inner series of stamens ca. $5 \mathrm{~mm}$ length, those of the outer series ca. $10 \mathrm{~mm}$ length, white, included; anthers 2-2.3 mm length, dorsifixed, white; ovary 2-4 mm length, inferior, flaky; style 0.9-1 mm length, cylindrical; trifid stigma, fimbriate; ovules obovate, numerous, stacked. Fruits and seeds not observed.

Distribution and habitat: Orthophytum disjunctum is endemic to Northeast Brazil (Smith \& Downs 1979, Forzza et al. 2014), being quite usual in the constitution of the flora of Bromeliaceae in rocky outcrops (Siqueira-Filho 2004). In the study area, it is found on islands of vegetation on the rock, colonizing flattened surfaces; as it was also recorded by Santos (2009) in a study on the vegetation of rocky outcrops in the Brazilian semiarid region.

Phenology: Found with flowers in April and July.

The species is distinguished by having patent leaves to the plant axis, coriaceous and densely lepidote, besides the inflorescence in panicle of fascicles and petals with fimbriate appendages. 

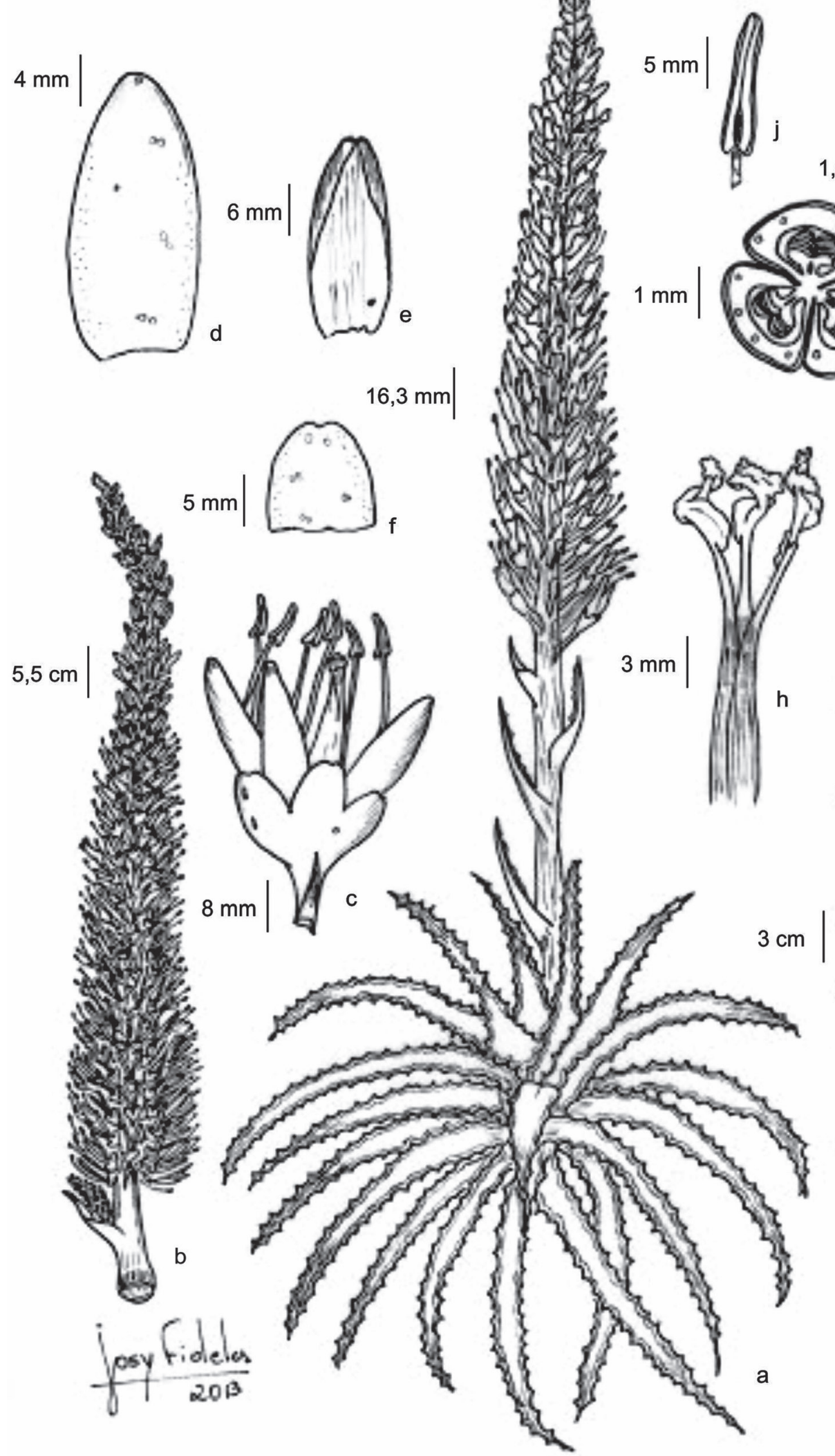
Specimens examined: BRAZIL. PARAíba: Pocinhos, 10-IV-2013, T.S. Silva 11 (ACAM). Puxinanã, 4-V-2013, T.S. Silva 15 (ACAM); idem, 6-VII-2013, T.S. Silva 30 (ACAM).

Additional specimens examined: BRAZIL. PARAíBA: Esperança, Lagoa de Pedra, 14-XI-2002, S. Pitrez et al. 462 (EAN). Fagundes, Pedra de Santo Antônio, 17-VII-2003, S. Pitrez et al. 375 (EAN).

7. Tillandsia loliacea Mart. ex Schult. \& Schult. f., Syst. Veg. 7(2): 1204. 1830.

Figure 5 a

Epiphyte, 5-11 cm height; not procumbent stem, inconspicuous. Leaves 1-3 cm length, polystichously, erect, aciculate, sericeous, spineless; sheath $0.2-0.4 \times 0.2-0.3 \mathrm{~cm}$, slightly different from blade, membranous, white; blade 1.2-2.2 $\times 0.1-0.3 \mathrm{~cm}$, linear, involute, chartaceous, apex long-attenuated, sericeous. Scape 3-7 cm length, undeveloped, cylindrical, cinereous, densely bracteate; bracts of the scape $1-2.3 \times 0.2-0.3 \mathrm{~cm}$, elliptic-lanceolate, imbricated, brownish, lepidote. Inflorescence 2-3.5 cm length, racemose, pauciflora, flexuous, exceeding leaves; floral bracts 0.7-0.8 $\times 0.3-0.4 \mathrm{~cm}$, showy, elliptic, imbricate, apex acute, lepidote. Flowers sessile, tubular, distichous, alternate, yellow; sepals $0.6-0.7 \times$ ca. $0.1 \mathrm{~cm}$, free, elliptic-lanceolate, glabrous, apex acuminate; petals ca. $0.8 \times 0.12 \mathrm{~cm}$, spatulate, membranous, yellow, apex rotund, slightly revoluto, patent at anthesis; stamens included, free; erect filaments, cylindrical; ovary ca. $1.2 \mathrm{~mm}$ length, superior; thick style; stigma simple. Capsule 1.8-3.4 cm, dehiscent, valves straight; seeds $2-3 \mathrm{~cm}$ length, plumose, with filiform appendages.

Distribution and habitat: The species is widely distributed species in South America, occurring from the Northeast to Southern Brazil, extending to Argentina, Bolivia and Paraguay (Fiorato 2009, Coffani-Nunes et al. 2010). In Paraíba State, Tillandsia loliacea was found in the agreste, mountainous forests and caatinga (Pontes \& Agra 2006); it is one of the most characteristic epiphytes in the semiarid area.

Phenology: Found fruited in April.

The species is characterized by its short size, up to $11 \mathrm{~cm}$ height, polystichously, short and erect leaves, inflorescence pauciflora, with alternating flowers and scape with imbricate and lepidote bracts along its entire length.
Specimen examined: BRAZIL. PARAíBA: Pocinhos, 26-III-2013, T.S. Silva 10 (ACAM).

Additional specimens examined: BRAZIL. PARAíBA: Ingá, Pedra do Ingá, 27-IX-1982, O.T. Moura s.n. (JPB 5412). Serra Branca, 8-III-2002, M.F. Agra et al. 5707 (JPB). São João do Tigre, APA das Onças, 5-VII-2005, P.C. Gadelha-Neto \& R.A. Pontes 290 (JPB).

8. Tillandsia polystachia (L.) L., Sp. P1. (ed. 2) 1: 410. 1762.

Figure $5 \mathrm{~b}$

Epiphyte, 30-80 cm height; not procumbent stem, inconspicuous; roots present, stiff. Leaves $14-42 \mathrm{~cm}$ length, polystichously, not forming tank, erect to slightly recurved, nerved, cinereous spineless; sheath $5-7 \mathrm{~cm} \times 3.4-5$, indistinct from blade, chataceous, brownish; blade 13.5-36 × 1.3-2.2 cm, triangularlanceolate, long-attenuated apex. Scape $16-50 \mathrm{~cm}$ length, erect, densely bracteate; bracts of the scape 4.5-27 × 1.6-2.2 cm, imbricated, oblong-acuminate, awned apex, vinaceous, cinereous. Inflorescence $11-45 \mathrm{~cm}$ length, panicle, simple to composed, linear; floral bracts $2-2.2 \times 0.9-1 \mathrm{~cm}$, showy, ovalelliptic, green-vinaceous, margin membranous, apex acuminate, exceeding the sepals. Flowers short pedicellate, tubular, lilacs; sepals ca. $1.8 \times 0.6 \mathrm{~cm}$, connate, elliptic-lanceolate, apex acute, keeled; petals ca. $4 \times 0.6 \mathrm{~cm}$, linear, membranous, lilacs, apex slightly revolute; stamens exsert, free; erect filaments, cylindrical, purple; dorsifixed anthers; ovarian ca. $5 \mathrm{~mm}$ length, superior; style 4-15 mm length; stigma spiral-conduplicate; ovules ca. $0.8 \mathrm{~mm}$ length, numerous. Capsule 4-5 cm length; seeds ca. $3.5 \mathrm{~cm}$ length, plumose, with filiform appendages.

Distribution and habitat: A widely distributed species, occurring in southern North America (southern United States and Mexico), Central America, Caribbean and South America (Colombia, Ecuador, Venezuela and Brazil). It was recorded for all regions of Brazil, being common in mountainous forests of the caatinga (Pontes \& Agra 2006, Fiorato 2009).

Phenology: Flowered in September.

Tillandsia polystachia stands out among the species of Tillandsia of the study area by its larger size, reaching about $80 \mathrm{~cm}$ height, with polystichously leaves arranged in rosette and forming tank.

Specimens examined: BRAZIL. PARAíBA: Pocinhos, 10-IV-2013, T.S. Silva 12 (ACAM); idem, 1-VII-2013, T.S. Silva 27 (ACAM). 


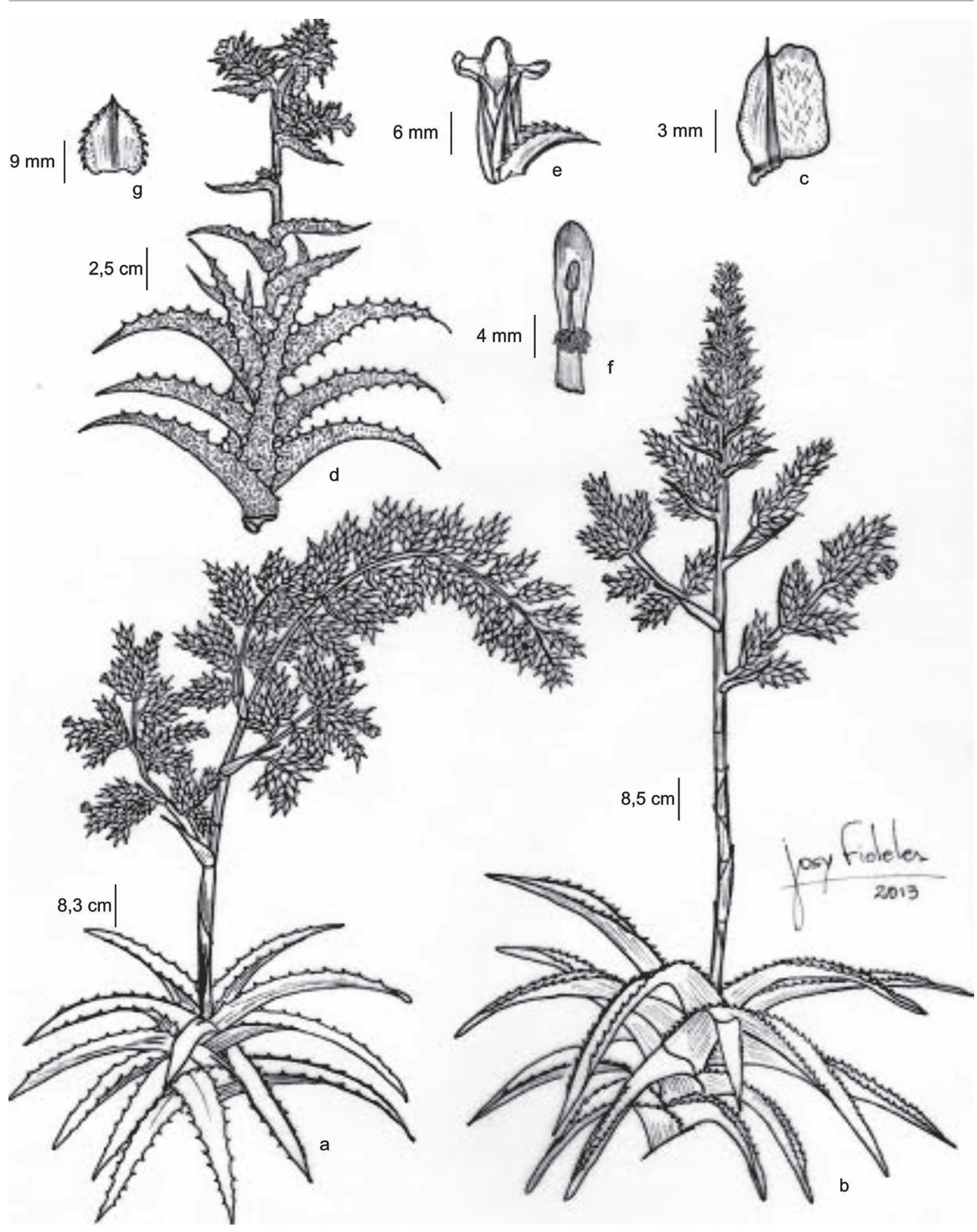

Figure 4. a. Hohenbergia catingae, habit. b-c. Hohenbergia horrida. b. Habit. c. Sepal. d-g. Orthophytum disjunctum. d. Habit. e. Flower and floral bract. f. Petal, stamen and petal appendage. g. Floral bract. 
Additional specimen examined: BRAZIL. PARAíBA: Areia, 26-X-2004, R. Pontes et al. 120 (JPB).

9. Tillandsia recurvata (L.) L., Sp. Pl. 1: 410. 1762. Figure 5 c-d

Epiphyte, 6-12 cm height; not procumbent stem, inconspicuous. Leaves 3-6.5 cm length, distichous, acerosous, strongly recurved, aciculate, sericeous, spineless; sheath 0.7-0.8 $\times 0.3-0.4 \mathrm{~cm}$, with a slightly different shape from the blade, membranous; blade 3-5 cm length, linear, cinereous, apex acute. Scape 3-9 cm length, poorly developed, erect, glabrous; bracts of the scape-1, lanceolate, basal. Inflorescence $1-1.5 \mathrm{~cm}$ length, exceeding the leaves, glabrous; floral bracts 7.5-8 $\times$ 3-3.5 mm, showy, elliptic-lanceolate, vinaceous-sericeous, not exceeding the sepals, apex acuminate. Flowers sessile, tubular, purplish; sepals ca. $0.7 \times 0.25 \mathrm{~mm}$, elliptic, imbricate, hyaline margin, acute apex, vinaceous, glabrous; petals ca. $0.12 \times 0.8 \mathrm{~cm}$, free, linear, purplish, apex obtuse, revolute; stamens 3.5-4.2 mm length, included, free; filaments $2.8-3 \mathrm{~mm}$ length, erect, cylindrical; anthers $0.8-1 \mathrm{~mm}$ length, dorsifixed, yellowish; ovary ca. $3 \mathrm{~mm}$ length, superior, dark brown; style $0.8-1 \mathrm{~mm}$ length, cylindrical; stigma simple; oval-elliptical ovules, numerous. Capsule 2.2-2.8 cm length; seeds ca. $2.2 \mathrm{~cm}$ length, plumose, with filiform appendages.

Distribution and habitat: Tillandsia recurvata is widely distributed in tropical America, occurring in southern North America, Central America, Caribbean and South America (Pontes 2005). The species is native to Brazil and is distributed in the Northeast, Southeast and South regions (Forzza et al. 2014).

Phenology: Flowered in March and fruited in March and April.

In Paraíba State, T. recurvata has been found in all types of ecosystems (Pontes \& Agra 2006). In the study area, it was recorded forming dense clumps and colonizing fruit trees as juazeiro (Ziziphus joazeiro Mart.), umbuzeiro (Spondias tuberosa Arruda) and jaboticabeira (Plinia cauliflora (Mart.) Kausel). This aspect can to corroborate for adaptation of this species to the outcrops, given that, according to Kersten (2010) the species of Tillandsia depend entirely on the moisture and nutrients removed from the air or the bark of phorophytes.

This species can be recognized for its aciculate, strongly recurved and sericeous leaves, forming dense populations on tree trunks. Furthermore, it is characterized by having escapement with only one bract.
Specimens examined: BRAZIL. PARAíBA: Pocinhos, 12-XII-2012, T.S. Silva 02 (ACAM); idem, 21-II-2013, T.S. Silva 05 (ACAM); idem, 8-V-2013, T.S. Silva 18 (ACAM); idem, 10-VI-2013, T.S. Silva 25 (ACAM). Puxinanã, 6-III-2013, T.S. Silva 07 (ACAM).

10. Tillandsia tenuifolia L., Sp. P1. 1: 286. 1753. Figure 5 e-i

Rupicolous, 12-22 cm height; not procumbent stem, inconspicuous to conspicuous, branched or unbranched, usually pending; roots present, stiff. Leaves 5-9 cm length, polystichously, not forming tank, erect to recurved, directed unilaterally or for all sides, spineless, lepidote; sheath $0.5-1 \times 1-1.5 \mathrm{~cm}$, strongly distinct from blade, membranous, white; blade 5-6.5 × 0.2-0.5 cm, triangular-lanceolate, chartaceous, apex long-attenuated, green or vinaceous. Scape 5-7.5 cm length, erect or slightly recurved, glabrous, densely bracteate; bracts of the scape 3.5-6 $\times 0.6-1 \mathrm{~cm}$, imbricate, elliptic to slightly ovate, margin membranous, apex awned, pinkish to greenish, glabrous. Inflorescence ca. $3.5 \mathrm{~cm}$ length, multiflora, 6-11 flowers, spiciform, ovoid to cylindrical, exceeding leaves; floral bracts 0.9-1.6 × 0.6-1.2 cm, oval-elliptic, involute, rosy, nerved, apex acuminate to awned, exceeding the sepals. Flowers short pedicellate, tubular, white; sepals $1-1.3 \times 0.3-0.5 \mathrm{~cm}, 1$ free and 2 connate, elliptic-lanceolate, keeled, margin hyaline, apex attenuated, white-greenish, glabrous; petals 1.3-1.8 $\times$ 0.3-0.4 cm, free, spatulate, white, apex obtuse, revolute; stamens 11-13 mm, included, epipetalous; filaments 9-11 mm length, compressed, plicate in the middle portion; anthers ca. $2 \mathrm{~mm}$ length basifixed, linear, white; ovary 2-3 mm length, superior, oval to globose, glabrous; style 8-1 mm, cylindrical, slender; trifid stigma, non-coiled; linear ovules. Fruits and seeds not observed.

Distribution and habitat: Tillandsia tenuifolia is found in Cuba, Guyana Shield, Venezuela, Bolivia, Brazil, Paraguay and Argentina (Pontes 2005, Fiorato 2009 and Coffani-Nunes et al. 2010). In Brazil there are records for almost every state in the northeastern region except Maranhão, Piauí and Rio Grande do Norte States; and all of the Midwest, Southeast and Southregions (Pontes 2005, Fiorato 2009, Forzza et al. 2014).

Phenology: Flowered in September.

According to Fiorato (2009) and CoffaniNunes et al. (2010), T. tenuifolia displays a high 


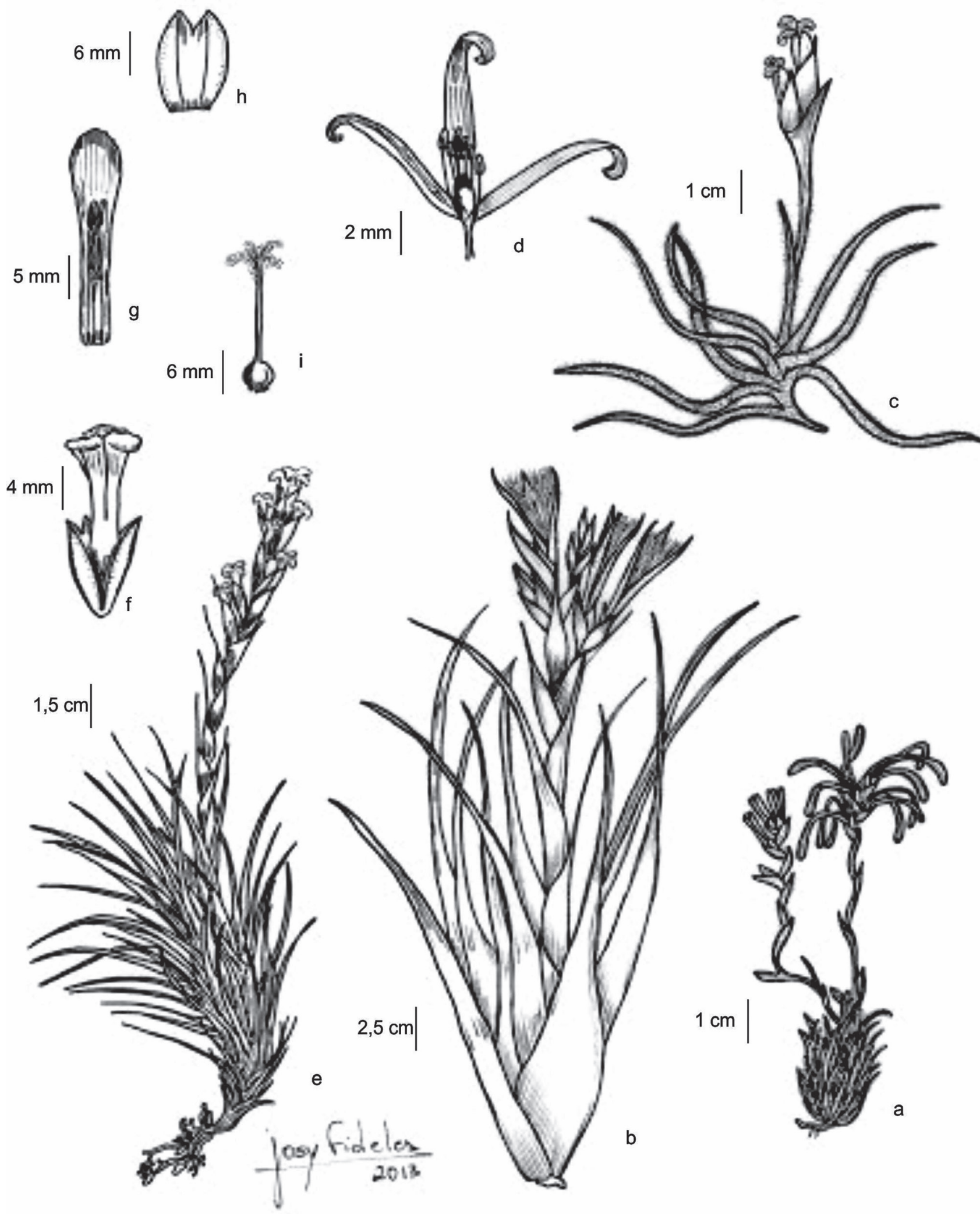

Figure 5. a. Tillandia loliacea, habit. b. Tillandsia polystachia, habit. c-d. Tillandsia recurvata. c. Habit. d. Flower, demonstrating batting corolla. e-i. Tillandsia tenuifolia. e. Habit. f. Flor. g. Petal and stamen. h. Gynoecium. i. Sepals, connate. 
morphological plasticity, especially in vegetative parts, being recognized five varieties. However, analysis of floral morphology indicates that the set of floral characters is constant. For this reason, such varieties were considered in this work as synonims due to the variations being inaccurate.

It is characterized for having polystichously leaves, usually directed unilaterally bracts along the pinkish scape with apex awned, two connate sepals and one free, connate petals and epipetalous stamens with plicated fillets.

Specimen examined: BRAZIL. Paraíba: Puxinanã, 29-IX-2012, T.S. Silva 1 (ACAM).

Additional specimen examined: BRAZIL. ParaíBA: Fagundes, 26-IX-2013, M. Medeiros 32 (ACAM). Pernambuco: Brejo da Madre de Deus, Bituri, 9-VIII-2008, L.P. Felix 12553 (EAN).
Orchidaceae A.Juss., Gen. P1.: 64-65. 1789.

In the study area were recorded six species distributed in five genera.

Orchidaceae is recognized as the largest family of Angiosperms, comprising approximately 24,500 species in 785 genera (Chase et al. 2003, Dressler 2005), distributed worldwide, but having the tropics as the main center of diversity (Dressler 1993). According to Barros et al. (2014), there are approximately 2,450 species allocated in 240 genera in the Brazilian territory, covering about 1,640 endemic species. For Paraíba State, 57 accepted names are recorded in a total of 593 species for the northeast region. Of the six species of Orchidaceae recorded in the study area, five were found in Pocinhos and three in Puxinanã; with one species Cyrtopodium holstii L.C. Menezes common to both sets of rocky outcrops studied (table 1).

Key to the Orchidaceae species from rocky outcrops of the cities of Pocinhos and Puxinanã

1. Plant without pseudobulbs

2. Unifoliolate; leaves conduplicate, fleshy, mucronate apex; sepals keeled, concrescent .... Acianthera ochreata

2. Plurifoliolate; not ridged, leaves flattened, membranous or chartaceous; sepals not keeled, free

3. Plants with globose tuberoid; leaves distichous; imbricate floral bracts; pedicel 1.1-2.5 cm length, calcarate flowers, cuculate dorsal sepal; lip linear Habenaria obtusa

3. Plants without globose tuberoids; leaves polystichous; floral bracts not imbricate; pedicel ca. $0.2 \mathrm{~cm}$ length, not calcarate flowers, oblong dorsal sepal; lip cuculate Prescottia plantaginifolia

1. Stem with pseudobulbous

4. Unifoliolate; leaves cylindrical, viscid; flowers long-pedicellate; lip simple; pollinia 8

Brassavola tuberculata

4. Plurifoliolate; flat leaves, membranous; flowers short-pedicellate; lip 3-lobed; pollinia 2

5. Sepals and petals of sinuated margin; corolla yellow-orange with red stains, central lobe of the lip of crisp margin Cyrtopodium holstii

5. Sepals and petals of sinuated margin; corolla greenish-yellow, devoid of blemishes, central lobe of the lip of entire margin Cyrtopodium flavum

1. Acianthera ochreata (Lindl.) Pridgeon \& M. W. Chase, Lindleyana 16(4): 245. 2001.

Figures 6 a-d, 7 a

Rupicolous, 9-11 cm height. Thin roots along the rhizome. Ramicaule cylindrical, 3-7 cm length, unifoliate, greenish-brown, bearing the remains of leaf sheaths. Leaves 5-9 $\times 1.8-2.1 \mathrm{~cm}$, sessile, oblong, conduplicated, fleshy, ridged, yellow-green or green-vinaceous, apex mucronate, mucro ca. $1 \mathrm{~mm}$ length. Inflorescence $2-3.5 \mathrm{~cm}$ length, racemose, terminal, erect or pendant, 6-10 flowers; peduncle 3-4.5 cm length, greenish-yellow; bracts of the peduncle 1.5-2.6 cm length, ovate, membranous, amplexicaule, apiculate apex; floral bracts $0.2-0.5 \mathrm{~cm}$ length, rhombic, membranous, centrally fleshy, apex cuspidate, amplexifloras. Flowers resupinate, short-pedicellate, pedicel $0.25-0.3 \mathrm{~cm}$ length, articulated with the ovary; sepals erect, oblonglanceolate, naviculate, concrescent, keeled, yellowishorange, fleshy, glabrous, acute apex, the dorsal $0.4-0.5 \times 0.15-0.2 \mathrm{~cm}$, lateral $0.2-0.3 \times 0.2-0.3 \mathrm{~cm}$; petals ca. $0.1 \times 0.1-0.2 \mathrm{~cm}$, oblong, translucent, punctuated, apex retuso, lip ca. $0.2 \mathrm{~cm}$ length, 3-lobed, yellow, fleshy, attached to the foot of the column, middle lobe $1-1.5 \times \mathrm{ca} .1 \mathrm{~mm}$, middle portion two calli, apex rounded, lateral lobes $1-1.5 \times 0.5-1 \mathrm{~mm}$, raised, rounded apex; column ca. $0.1 \mathrm{~cm}$ length, serrated apex, pollinia 2. Capsule 1.5-1.9 $\times$ 0.5-0.6 cm, ellipsoid.

Distribution and habitat: According to Barros et al. (2014), this species is endemic to Brazil, being 


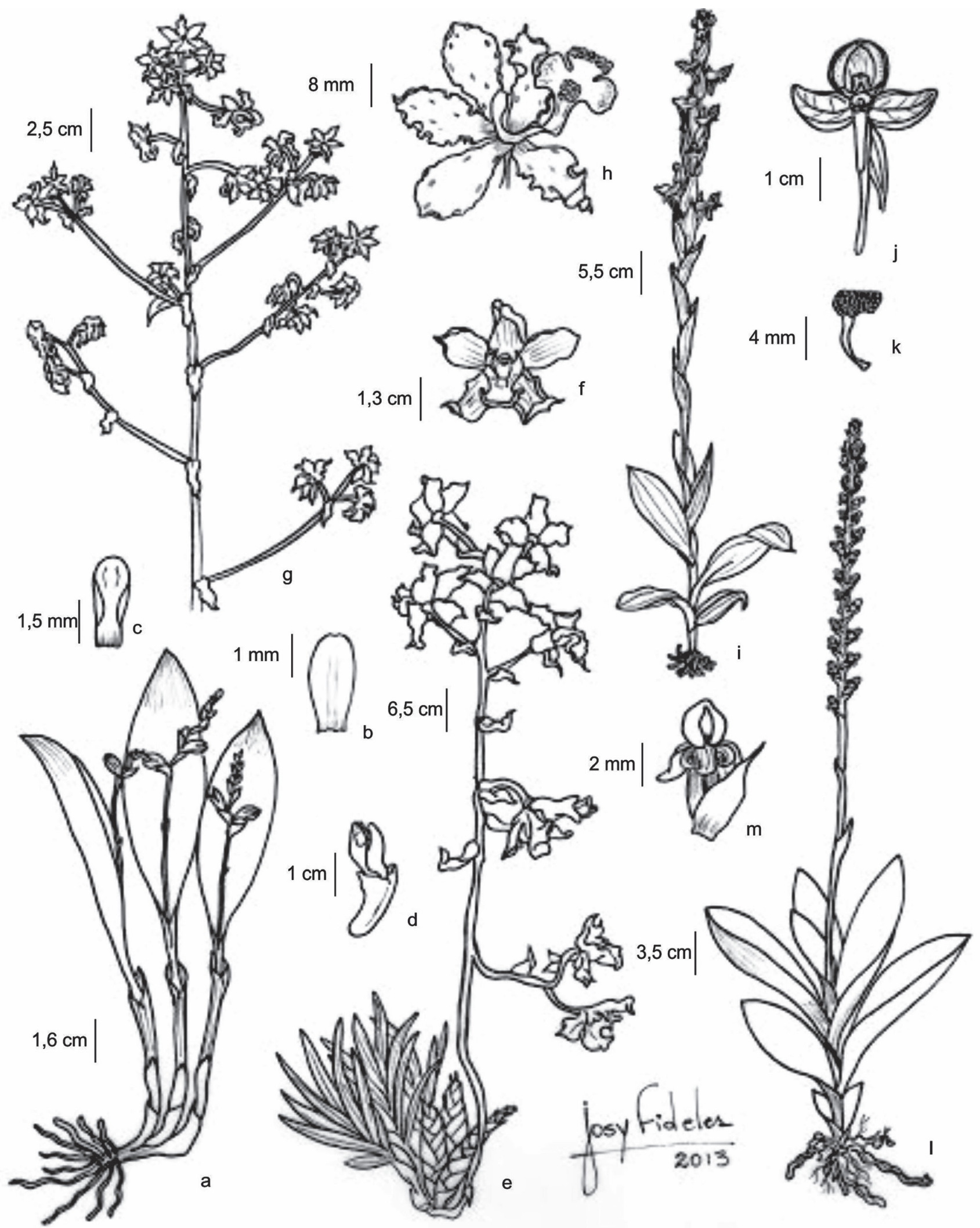

Figure 6. a-d. Acianthera ochreata. a. Habit. b. Petal. c. Lip. d. Column, lip and pedicel, side view. e-f. Cyrtopodium flavum. e. Habit. f. Flower. g-h. Cyrtopodium holstii. g. Inflorescence. h. Flower. i-k. Habenaria obtusa. i. Habit. j. Flower. k. Pollinia. 1-m. Prescottia plantaginifolia. 1. Habit. m. Flower and floral bract. 
recorded in Caatinga, Cerrado and Atlantic Forest in the States of Alagoas, Bahia, Paraíba, Pernambuco and Minas Gerais. In the study area it is found forming carpets on top of the outcrop amid species of the families Apocynaceae, Euphorbiaceae and Bromeliaceae.

Phenology: Found flowered in May and fruited in September.

Acianthera ochreata was originally described by Lindley in 1836 based on a specimen obtained in the Serra Monte Santo, Bahia State, under Pleurothallis ochreata (Azevedo \& Van den Berg 2007, Borba \& Semir 2001, Borba et al. 2002). However, after a redefinition of the subtribe Pleurothallidinae based on phylogenetic analyses using DNA sequences the species of the genus Pleurothallis were transferred to Acianthera (Pridgeon et al. 2001, Pridgeon \& Chase 2003), which was recovered by Luer (2004).

This species can be easily recognized for its fleshy leaves, conduplicated, yellow-greenish or green-vinaceous, flowers with concrescente sepals and 3-lobed lip, swith two callous on the middle lobe.

Specimens examined: BRAZIL. Paraíba: Pocinhos, 29-V-2013, T.S. Silva 20 (ACAM); idem, 1-VII-2013, T.S. Silva 28(ACAM); idem, 31-XI-2013, T.S. Silva 39 (ACAM). Puxinanã, 4-V-2013, T.S. Silva 17 (ACAM); idem, 6-VII-2013, T.S. Silva 33 (ACAM).

2. Brassavola tuberculata Hook., Bot. Mag. 56: t. 2878. 1829.

Rupicolous, 12-30 cm length. Thick roots along the rhizome. Pseudobulbs unifoliolate; $1-3 \mathrm{~cm}$ length, reptant, oval, greenish-brown. Leaf 8.5-25 cm length, cylindrical, viscid, grooved along its entire length, apex acute. Inflorescence 8-16 cm, terminal, racemose; floral bracts ca. $0.4 \mathrm{~cm}$, triangular-lanceolate, paleaceous, apex acute. Flower resupinate, longpedicellate, white; pedicel ca. $7 \mathrm{~cm}$, including ovary; sepals white-yellowish, dorsal sepal 3-4 $\times 0.4-0.5 \mathrm{~cm}$, filiform, apex acute; lateral sepals 3-3.7 $\times 0.5-0.6 \mathrm{~cm}$, symmetricals, filiform, membranous, apex acute; petals $0.2-0.3 \times 3.4-4 \mathrm{~cm}$, filiform, white-greenish; lip 1.2-2 $\times 2.2-2.8 \mathrm{~cm}$, simple, deltoid, articulated at the foot of the column, white, yellowish central callus, slightly undulate margin, apex obtuse to acuminate; column ca. $1 \mathrm{~cm}$ length, suberect, white; pollinia 8 . Fruits not observed.

Distribution and habitat: Brassavola tuberculata is recorded for Bolivia and Brazil, where it is distributed in the states of shoreline, with the exception of Rio Grande do Norte and Espirito Santo States; and in the State of Tocantins, Northern Region (Azevedo \& Van den Berg 2007, Barros et al. 2014). Found in outcrops of the municipality of Puxinanã forming dense populations on the slopes of rock, mostly exposed to the sun.

Phenology: Flowered in February and April (from February to April).

Species easily recognized by the cylindrical leaves, sulcate along its entire length, long-pedicellate flowers (ca. $7 \mathrm{~cm}$ ), white-yellowish petals and sepals, filiform, deltoid lip with central yellow callus and 8 pollinia. Specimen examined: BRAZIL. PARAíBA: Puxinanã, 6-VII-2013, T.S. Silva 32 (ACAM).

Additional specimens examined: BRAZIL. PARAíBA: Araruna, Parque Estadual Pedra da Boca, 30-IV-2008, P.C. Gadelha-Neto et al. 2204 (JPB). João Pessoa, Orquidário, 08-II-1998, F. Eduardo 02 (JPB).

3. Cyrtopodium flavum Link \& Otto ex Rchb., Iconogr. Bot. Exot. 3: 7, t. 214. 1830.

Figures 6 e-f, 7 e

Rupicolous, cespitose plant, Pseudobulbous plurifoliolate, fusiform, $25-50 \mathrm{~cm}$ length. Leaves 20-40 cm length, flat, long-elliptic, membranous, plicate, acute apex. Inflorescence 13.9-19.3 cm length, raceme; bracts of the peduncle 1.8-3.5 $\times 0.8-1 \mathrm{~cm}$, lanceolate, membranous, apex acuminate; floral bracts 1.5-2.5 × 0.1-1 cm, lanceolate, membranous, undulate, apex acuminate. Flowers resupinate, short-pedicellate, pedicel ca. $2 \mathrm{~cm}$ length, green; dorsal sepal greenish yellow 1.3-1.7 $\times$ 0.7-0.8 cm, elliptic, sinuous margin, acute apex, lateral sepals 1.5-1.8 $\times$ ca. $0.9 \mathrm{~cm}$, elliptic, sinuous margin, devoid of blemishes; petals 1-1.4 × 0.7-1.1 cm, obovate, membranous, greenish-yellow, devoid of blemishes, sinuous margin, acute apex, inflection; lip ca. $1.2 \mathrm{~cm}$ length, 3-lobed, articulate with column foot, lateral lobes 8-11 × 5-7 mm, auricular, apex rounded, yellowish, central lobe $8-11 \times 10-12 \mathrm{~mm}$, orbicular, margin entire, apex retuse; column 0.5-0.6 cm length, yellow-greenish; pollinia 2. Capsule 5-6 $\times 1.8-2 \mathrm{~cm}$, ellipsoid.

Distribution and habitat: Species endemic to Brazil, occurring in the Northeast, South and Southeast regions (Barros et al. 2014). In the study area, it was found at the edge of an extensive island of vegetation located on the plateau of the outcrop in the municipality of Pocinhos. 


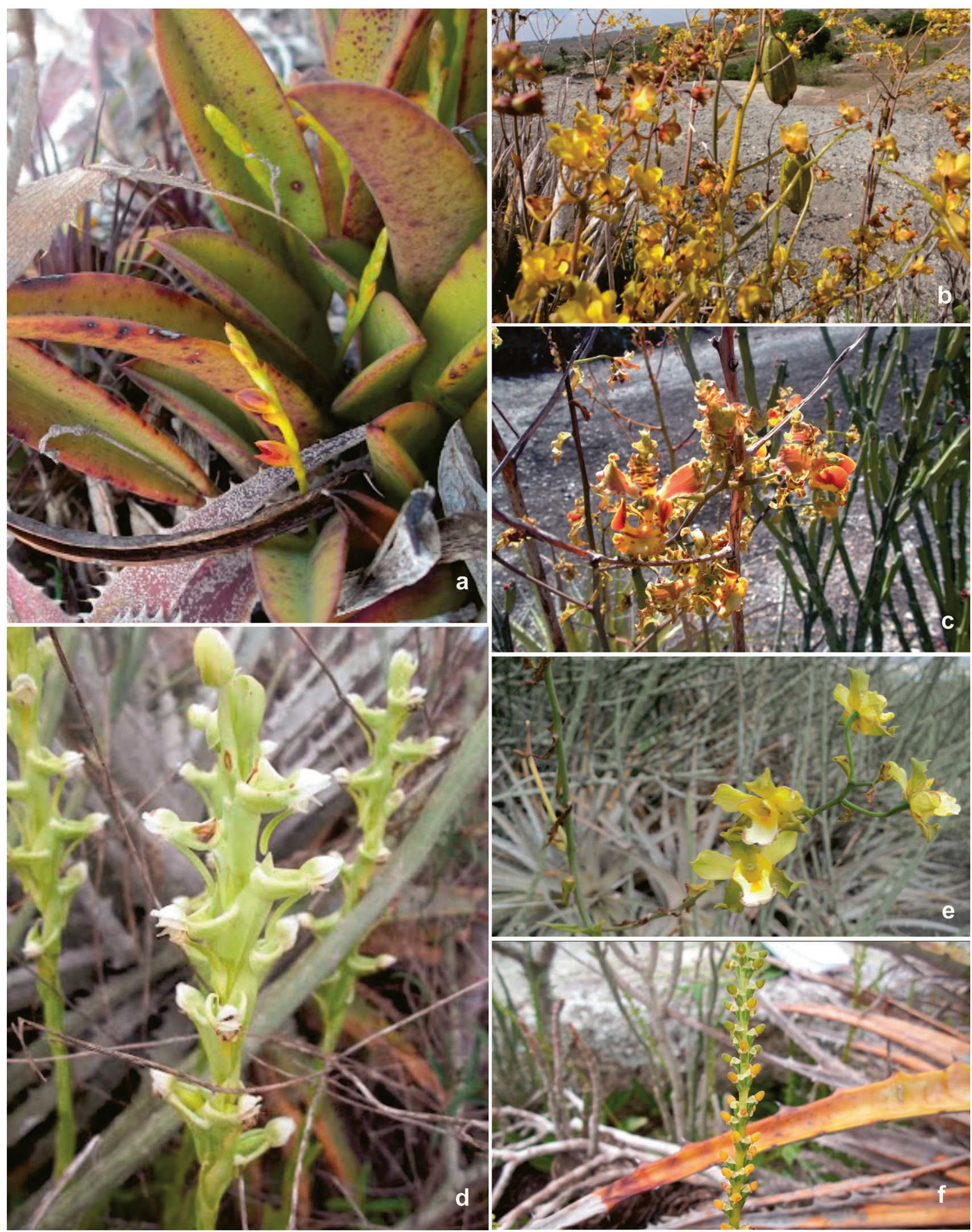

Figure 7. Orchidaceae species in Pocinhos and Puxinanã rocky outcrops: a. Acianthera ochreata. b-c. Cyrtopodium holstii. d. Habenaria obtusa. e. Cyrtopodium flavum. f. Prescottia plantaginifolia. 
Phenology: Flowered and fruited in January.

Cyrtopodium polyphyllum (Vell.) Pabst ex F. Barros it is synonymized under Cyrtopodium flavum (Pessoa \& Alves 2011, Barros et al. 2014). It differs from other species of Cyrtopodium found in this study for having yellow flowers, devoid of red blemishes, sinuous margin and central lobe of the lip with entire margin.

Specimen examined: BRAZIL. Paraíba: Pocinhos, 28-I-2013, T.S. Silva 4 (ACAM).

Additional specimen examined: BRAZIL. ParaíBA: João Pessoa, 17-I-2013, O.T. Moura 1524 (ACAM).

4. Cyrtopodium holstii L.C. Menezes, Schlechteriana 4(4): 149. 1993.

Figures 6 g-h, 7 b-c

Rupicolous cespitose plant. Pseudobulbous plurifoliolate, fusiform $27-53 \mathrm{~cm}$ length. Leaves 30-45 cm, flat, long-elliptic, membranous, plicate, acute apex. Inflorescence $14-36.5 \mathrm{~cm}$ length, raceme; bracts of the peduncle $0.4-0.6 \mathrm{~cm}$ length, linear-lanceolate, apex acute; floral bracts 0.9-2.8 $\times 0.6-1.5 \mathrm{~cm}$, lanceolate, membranous, undulate, apex acuminate. Flowers $2.5-3 \mathrm{~cm}$ length, resupinate, short-pedicellate, pedicel ca. $3 \mathrm{~cm}$ length, green; dorsal sepal 1.2-1.6 × 0.4-0.5 cm, elliptic, margin crisped, apex acute, yellow, with red stains, lateral sepals 1.1-1.4 × 0.4-0.6 cm, elliptic, margin crisped, apex acute, yellow with red stains; petals 1.3-1.5 × 0.6-0.8 cm, obovate, yellow-orange, with red stains, punctuated margin, apex acute; lip ca. $1.3 \times 0.9 \mathrm{~cm}, 3$-lobed, articulate with column foot, lateral lobes 6-8 $\times$ 5-7 mm, narrow-oblong, yellow-red, margin entire, apex rotund, central lobe 9-12 $\times 5-9 \mathrm{~mm}$, margin crisped; column ca. $0.7 \mathrm{~cm}$ length, greenish-yellow; pollinia 2. Capsule $6-6.2 \times 1.8-2.0 \mathrm{~cm}$, ellipsoid.

Distribution and habitat: According to Barros et al. (2014), this species is endemic to Brazil, having as synonymous Cyrtopodium inaldianum L.C. Menezes. It was recorded for most states in the Northeast, States of Pará (North), Espírito Santo and Minas Gerais (Southeast), being associated with areas of Caatinga, Atlantic Forest and Amazon Rainforest. It was found in the rocky outcrops of Pocinhos.

Phenology: Flowered in March and fruited in March and July.
Cyrtopodium holstii is morphologically related to C. flavum, also recorded in this study (see comments on C. flavum). However, it can be distinguished of this later for having sepals and petals with red stains and crisped margin, lip with lateral lobes of entire margin and central lobe margin crisped.

Specimens examined: BRAZIL. PARAíBA: Pocinhos, 26-III-2013, T.S. Silva 9 (ACAM); idem, 31-V-2013, T.S. Silva 22 (ACAM). Puxinanã, 4-V-2013, T.S. Silva 14 (ACAM).

5. Habenaria obtusa Lindl., Gen. Sp. Orchid. P1.: 315. 1835.

Figures $6 \mathrm{i}-\mathrm{k}, 7 \mathrm{~d}$

Terrestrial, 27.5-68 cm length. Roots thin coming directly from cauloma, with globose tuberoids. Stem cylindrical, $10-15 \mathrm{~cm}$ length, plurifoliolate. Leaves $6-16.5 \times 1.9-2.6 \mathrm{~cm}$, flat, not grooved, distichous, amplex-stems, lanceolate, membranous, green, glossy, nerved, acute or obtuse apex. Inflorescence 14.5-25.5 cm length, racemose, erect, 12-25-flora; floral bracts 1.9-3.4 × 0.7-1.2 cm, imbricated, oblong-lanceolate, membranous, apex acute. Flowers 1.5-2.5 cm length, calcarate, pedicellate, pedicel 1.1-2.5 cm length, greenish; sepals not keeled, free, dorsal sepal $0.8-1 \times 0.6-0.8 \mathrm{~cm}$, cuculate, ovate, apex obtuse, white, lateral sepals 1.1-1.2 $\times 0.5-0.6 \mathrm{~cm}$, ovate-falcate, acute apex, white-greenish; petals $0.7-0.9 \times 0.2-0.4 \mathrm{~cm}$, spatulate, white, hyaline, apex rounded; lip 1-1.6 $\times 0.2-0.3 \mathrm{~cm}$, entire, simple, linear, curved, without lateral projections, curved, based prolonged on calcar, shoeing 3.2-4.1 cm length, cylindrical, erect, white, obscured by bracts; column 0.4-0.6 cm, free; pollinia 2, sected, long caudicle. Capsule 1.2-1.6 cm length, ellipsoid.

Distribution and habitat: Widely distributed in Brazil, Colombia, Ecuador, Guyana, Paraguay, Peru, Suriname and Venezuela (Batista et al. 2008). It occurs in vegetation islands on the slope of the outcrop of the municipality of Pocinhos.

Phenology: Flowered in August and fruited in September.

Habenaria obtuse it is distinguished among the Orchidaceae species registered in the studied area by having globose tubers in roots and by the imbricate floral bracts, calcarate flowers with wedge covered by bracts and dorsal sepal cuculate.

Specimen examined: BRAZIL. PARAíBA: Pocinhos, 6-VIII-2013, T.S. Silva 35 (ACAM); idem, 21-IX-2013, T.S. Silva 37 (ACAM). 
6. Prescottia plantaginifolia Lindl. ex Hook., Exotic Flora 2: t. 115. 1824.

Figures $61-\mathrm{m}, 7 \mathrm{f}$

Rupicolous, 28-49.5 cm length. Roots thick coming out of the base of cauloma. Stem cylindrical, plurifoliolate. Leaves 8.5-21.2 × 1.3-3.7 cm, polystichous, forming a rosette, flat, not grooved, ampletive, elliptic-lanceolate, glossy, chartaceous, green, prominent midrib, apex acute, not mucronate. Inflorescence $5-18.5 \mathrm{~cm}$ length, racemose, $25-50$ flora, erect, terminal; floral bracts $0.5-0.9 \mathrm{~cm}$ length, not imbricated, lanceolate, membranous, apex attenuated; pedicel ca. $0.2 \mathrm{~cm}$ length, green. Flowers $0.2-0.3 \mathrm{~cm}$ length, no resupinate, green when young and yellow when mature, short-pedicellate; sepals not keeled, free, dorsal sepal ca. $0.2 \times 0.1 \mathrm{~cm}$, oblong, obtuse, white, lateral sepals $0.2-0.3 \times 0.1-0.2 \mathrm{~cm}$, oblong, slightly acute; petals ca. $0.1 \times 2.3 \mathrm{~cm}$, linear, obtuse; lip 2-2.2 mm length, simple, cuculate, auriculate, column ca. $0.2 \mathrm{~cm}$, green; pollinia 4 , slightly flattened, indivisible. Capsule ca. $0.4 \mathrm{~cm}$ length, ellipsoid.

Distribution and habitat: The species occurs in Argentina and the Brazilian East coast of Paraíba to Santa Catarina and Goiás States (Cunha \& Forzza 2007, Barros et al. 2014). In the study area was found forming small populations primarily in crevices of rocky located on the edge of central outcrop or composing vegetation islands species of Bromeliaceae and Euphorbiaceae in the municipality of Pocinhos.

Phenology: Flowered and fruited in September.

Some authors consider Prescottia plantaginifolia as homotypical synonymous of $P$. plantaginea Hook. (Pabst \& Dungs 1975, Azevedo \& Van den Berg 2005, Cunha \& Forzza 2007, Saddi 2008). However, according to Forzza et al. (2014) and the database of the Missouri Botanical Garden (2014), P. plantaginifolia is the correct name for this species.

It is characterized by having leaves forming a basal rosette and inflorescence with flowers $0.2-0.3 \mathrm{~cm}$ length, yellowish-green, pedicel with approximately $0.2 \mathrm{~cm}$ length and cuculate lip.

Specimen examined: BRAZIL. PARAíBA: Pocinhos, 3-IX-2013, E.C.S. Costa 159 (ACAM); idem, 10-IX2013, T.S. Silva 36 (ACAM).

\section{Conclusions}

This work contributed to the expansion of the knowledge on the taxonomy and representativeness of the families Bromeliaceae and Orchidaceae in rocky environments in the Brazilian northeastern, especially to the State of Paraiba, besides to provide data for conduct studies on different aspects of such families and data for the implementation of conservation policies of the flora associated to rocky environments of Paraíba State.

\section{Acknowledgements}

We thank to Josycleide Fidelis for preparing the illustrations. To the curators and employees of the herbaria EAN and JPB for permission to examine their collections. The first Author thanks to $\mathrm{CNPq}$ (Conselho Nacional de Desenvolvimento Científico e Tecnológico) for the fellowship of the Scientific Initiation Scholarship through the Scientific Initiation Program at the Universidade Estadual da Paraíba (UEPB - PIBIC 2013/2014)). J.I.M. Melo (Proc. n. 302751/2012-2) and L.P. Felix (Proc. n. 309215/2013-7) thank to CNPq (Conselho Nacional de Desenvolvimento Científico e Tecnológico) for the Research Productivity Fellowship (PQ-2). To Elainne Cristina Silva Costa her valorous help in the final treatment of the figures.

\section{Literature cited}

AESA, Agência Executiva de Gestão das Águas do Estado da Paraíba. 2014. Geoportal. Available at: http://www.aesa.pb.gov.br/geoprocessamento/ geoportal/mapas.html. (access in 3-IX-2014).

Alves, M., Araújo, M.F., Maciel J. R. \& Martins, S. (ed.). 2009. Flora de Mirandiba. Associação Plantas do Nordeste, Recife. 357 p.

Andrade, L.A., Oliveira, F.X., Neves, C.M. L. \& Félix, L.P. 2007. Análise da vegetação sucessional em campos abandonados do agreste paraibano. Revista Brasileira de Ciências Agrárias 2: 135-142.

Angelim, A.E.S., Moraes, J.P.S., Silva, J.A.B. \& Gervásio, R.C.R.G. 2007. Revista Brasileira de Biocências 5: 1065-1067.

Araújo, F.S., Oliveira, R.F. \& Lima-Verde, L.W. 2008. Composição, espectro biológico e síndromes de dispersão da vegetação de um inselbergue no domínio da caatinga, Ceará. Rodriguésia 59: 659-671.

Azevedo, C.O. \& Van den Berg, C. 2005. Proposals to conserve the name Prescottia with that spelling and $P$. plantaginea against $P$. plantaginifolia (Orchidaceae). Taxon 54: 1105-1106.

Azevedo, C.O. \& Van den Berg, C. 2007. A família Orchidaceae no Parque Municipal de Mucugê, Bahia, Brasil. Hoehnea 34: 1-47. 
Barros, F., Batista, J.A.N. \& Bianchetii, L.B. 2003. Epitypification and taxononomic elucidation of some Brazilian taxa of Cyrtopodium R. Br. (Orchidaceae). International Association for Plant Taxonomy (IAPT) 4: 841-849.

Barros, F., Vinhos, F., Rodrigues, V.T., Barberena, F.F.V.A., Fraga, C.N., Pessoa, E.M., Forster, W. \& Menini-Neto, L. 2014. Orchidaceae. In: Lista de Espécies da Flora do Brasil. Jardim Botânico do Rio de Janeiro, Rio de Janeiro. Available at: http://reflora. jbrj.gov.br/jabot/floradobrasil. (access in 3-IX-2014).

Barthlott, W., Gröger, A. \& Porembski, S. 1993. Some remarks on the vegetation of tropical Inselbergs: diversity and ecological differentiation. Biogeographica 69: 105-124.

Batista, J.A.N., Silva, J.B.F. \& Bianchetti, L.B. 2008. The genus Habenaria (Orchidaceae) in the Brazilian Amazon. Revista Brasileira de Botânica 31: 105-134.

Borba, E.L. \& Semir, J. 2001. Pollinator specificity and convergence in fly-pollinated Pleurothallis (Orchidaceae) species: a multiple population approach. Annals of Botany 88: 75-88.

Borba, E.L., Shepherd, G.J., Van den Berg, C. \& Semir, J. 2002. Floral and vegetative morphometrics of five Pleurothallis (Orchidaceae) species: correlation with taxonomy, phylogeny, genetic variability and pollination systems. Annals of Botany 90: 1-12.

Brasil. Fundação Instituto Brasileiro de Geografia e Estatística - IBGE. 1992. Divisão regional do Brasil em mesorregiões e microrregiões geográficas, vol. 2. IBGE, Rio de Janeiro. Available at: http://biblioteca. ibge.gov.br/visualizacao/livros/liv2269_3.pdf. (access in 3-IX-2014).

Brasil, Ministério da Agricultura. Equipe de pedologia e fertilidade do solo. Divisão de Agrologia - SUDENE. 1972. Levantamento exploratório - Reconhecimento de solos do Estado da Paraíba. Rio de Janeiro, pp. 41-45.

Cavallari, M.M. 2004. Estrutura genética de populações de Encholirium (Bromeliaceae) e suas implicações para sua conservação. Dissertação de Mestrado, Escola Superior de Agricultura Luiz de Queiroz, Piracicaba.

Chase, M.W., Cameron, K.M., Barrett, R.L. \& Freudenstein, J.V. 2003. DNA data and Orchidaceae systematics: a new phylogenetic classification. In: K.W. Dixon, S.P. Kell, R.L. Barrett \& P.J. Cribb (eds.). Orchid conservation. Natural History Publications: 69-89.

Coffani-Nunes, J.V., Versieux, L.M., Wanderley, M.G.L. \& Pirani, J.R. 2010. A flora da Serra do Cipó, Minas Gerais: Bromeliaceae - Tillandsioideae. Boletim de Botânica da Universidade de São Paulo 28: 35-54.

Cunha, M.F.B. \& Forzza, R.C. 2007. Orchidaceae no Parque Natural Municipal da Prainha. Acta Botanica Brasilica 21: 383-400.

Dressler, R. L. 1993. Phylogeny and classification of the orchid family. Dioscorides Press, Portland.
Dressler, R. L. 2005. How many orchid species? Selbyana 26: $155-158$

Fiorato, L. 2009. O gênero Tillandsia L. (Bromeliaceae) no Estado da Bahia, Brasil. Dissertação de Mestrado, Instituto de Botânica, São Paulo.

Forzza, R.C. 2005. Revisão taxonômica de Encholirium Mart. ex Schult. \& Schult. f. (Pitcairnioideae Bromeliaceae). Boletim de Botânica da Universidade de São Paulo 23: 1-49.

Forzza, R.C., Costa A., Siqueira-Filho, J.A., Martinelli, G., Monteiro, R. F., Santos-Silva, F., Saraiva, D.P., Paixão-Souza, B., Louzada, R.B. \& Versieux, L. 2014. Bromeliaceae. In: Lista de Espécies da Flora do Brasil. Jardim Botânico do Rio de Janeiro, Rio de Janeiro. Available at: http://reflora.jbrj.gov.br/jabot/floradobrasil (access in 3-IX-2014).

Gonçalves, E.G. \& Lorenzi, H. 2011. Morfologia vegetal: Organografia e dicionário ilustrado de morfologia das plantas vasculares, 2 ed. Instituto Plantarum, São Paulo.

Kersten, R.A. 2010. Epífitas vasculares - histórico, participação taxonômica e aspectos relevantes, com ênfase na Mata Atlântica. Hoehnea 37: 9-38.

Koch, A.K. \& Silva, C.A. 2012. Orquídeas nativas de Mato Grosso. Carlini \& Caniato Editorial, Cuiabá.

Lima, T.T. 2008. Bromeliaceae da Serra da Mantiqueira: distribuição geográfica e conservação. Dissertação de Mestrado, Instituto de Botânica, São Paulo.

Luther, H.E. 2008. An alphabetical list of bromeliad binomials. 11 ed. The Bromeliad Society International, Sarasota.

Luer, C.A. 2004. New genera and combinations in Pleurothallidinae. Icones Pleurothallidinarum XXVI. Monographs in Systematic Botany from the Missouri Botanical Garden 95: 253-265.

Luiz-Santos, A. \& Wanderley, M.G.L. 2012. Flora da Serra do Cipó, Minas Gerais: Bromeliaceae Bromelioideae. Boletim de Botânica da Universidade de São Paulo 30: 89-107.

Meirelles, S.T., Pivello, V.R. \& Joly, C.A. 1999. The vegetation of granite rock outcrops in Rio de Janeiro, Brazil, and the need for its protection. Environmental Conservation 26: 10-20.

Monteiro, R.F. \& Forzza, R.C. 2008. A família Bromeliaceae no Parque Estadual do Ibitipoca, Minas Gerais, Brasil. Boletim de Botânica da Universidade de São Paulo 26: 7-33.

Oliveira, R.B. \& Godoy, S.A.P. 2007. Composição florística dos afloramentos rochosos do Morro do Forno, Altinópolis, São Paulo. Biota Neotropica 7: 37-47.

Pabst, G.F.J. \& Dungs, F. 1975. Orchidaceae Brasilienses. Brücke-Verlag Kurt Schmersow, Hildesheim.

Pabst, G.F.J. \& Dungs, F. 1977. 2 v. Orchidaceae Brasilienses, Brücke-Verlag Kurt Schmersow, Hildesheim. 
Pansarin, L.M., Pansarin, E.R. \& Sazima, M. 2008. Reproductive biology of Cyrtopodium polyphyllum (Orchidaceae): a Crystopodiinae pollinated by deceit. Plant Biology 10: 650-659.

Peel, M.C., Finlayson, B.L. \& McMahon, T.A. 2007. Updated world map of the Köppen-Geiger climate classification. Hydrology and Earth System Sciences Discussions 4: 439-473.

Pereira, I.M., Andrade, L.A., Barbosa, M.R.V. \& Sampaio, E.V.S.B. 2002. Composição florística e análise fitossociológica do componente arbustivoarbóreo de um remanescente florestal no agreste paraibano. Acta Botanica Brasilica 16: 357-369.

Pessoa, E. \& Alves, M. 2011. Orchidaceae Juss. na Serra de Itabaiana, Sergipe, Brasil. Revista Caatinga 24: 102-114.

Pessoa, E. \& Alves, M. 2012. Flora da Usina São José, Igarassu, Pernambuco: Orchidaceae. Rodriguésia 62: 341-356.

Pessoa, E. \& Alves, M. 2014. Orchidaceae em afloramentos rochosos do estado de Pernambuco, Brasil. Rodriguésia 65: 717-734.

Pessoa, H.L., Lima, A.C.S., Reis, D.A.R., Argento, R.F. \& Pereira, M.C. 2011. Coleções particulares de orquídeas na cidade de Rio Paranaíba e sua contribuição para identificação dos gêneros nativos da região. Evolução e Conservação da Biodiversidade 2: 29-33.

Pitrez, S.R. 2006. Florística, fitossociologia e citogenética de angiospermas ocorrentes em inselbergues. Tese de Doutorado, Universidade Federal da Paraíba, João Pessoa.

Pontes, R.A.S. 2005. A família Bromeliaceae na floresta atlântica da Paraíba. Dissertação de Mestrado, Instituto de Pesquisas Jardim Botânico do Rio de Janeiro - Escola Nacional de Botânica Tropical, Rio de Janeiro.

Pontes, R.A.S. \& Agra, M.F. 2006. Flora da Paraíba, Brasil: Tillandsia L. (Bromeliaceae). Rodriguésia 57: 47-61.

Porembski, S. 2007. Tropical inselbergs: habitat types, adaptive strategies and diversity patterns. Revista Brasileira de Botânica 30: 579-586.

Porembski, S., Martinelli, G., Ohlemüller, R. \& Barthlott, W. 1998. Diversity and ecology of saxicolous vegetation mats on inselbergs in the Brazilian Atlantic rainforest. Diversity and Distributions 4: 107-119.

Porto, P.A.F., Almeida, A., Pessoa W.J., Trovão, D. \& Felix, L.P. 2008. Composição florística de um inselbergue no Agreste Paraibano, Município de Esperança, Nordeste do Brasil. Revista Caatinga 21: 214 .
Pridgeon A.M. \& Chase, M.W. 2003. Phylogenetics of the subtribe Pleurothallidinae (Epidendreae: Orchidaceae) based on combined evidence from DNA sequences. Lankesteriana 7: 49-50.

Pridgeon, A.M., Solano, R. \& Chase, M.W. 2001. Phylogenetic relationships in Pleurothallidinae (Orchidaceae): combined evidence from nuclear and plastid DNA sequences. American Journal of Botany 88: 2286-2308.

Rocha, M.A.C. 2010. Multiplicação e conservação de Bromeliaceae ornamentais. Tese de Doutorado, Universidade Federal do Recôncavo da Bahia, Cruz das Almas.

Saddi, E.M. 2008. Orchidaceae dos Afloramentos Rochosos da Pedra da Gávea, Parque Nacional da Tijuca, Rio de Janeiro. Dissertação de Mestrado, Instituto de Pesquisas Jardim Botânico do Rio de Janeiro, Rio de Janeiro.

Sarthou, C., Samadi, S. \& Boisseler-Dubayle, M.C. 2001. Genetic structure of the saxicole Pitcairnia geyskesii (Bromeliaceae) on inselbergs in French Guiana. American Journal of Botany 88: 861-868.

Santos, P.R.G. 2009. A vegetação em afloramentos rochosos no semiárido: diversidade e respostas ao ambiente. Dissertação de Mestrado, Universidade Federal de Pernambuco, Recife.

Siqueira-Filho, J.A. 2004. As bromélias nos Brejos de Altitude em Pernambuco: riqueza de espécies e status de conservação. In: K.C. Pôrto, J.J.P. Cabral \& M. Tabarelli (eds.). Brejos de altitude em Pernambuco e Paraíba: história natural, ecologia e conservação. Ministério do Meio Ambiente, Brasília, pp. 99-110.

Smith, L.B. \& Downs, R.J. 1974. Pitcairnioideae. In: Flora Neotropica, pp. 1-658. Hafner Press, New York.

Smith, L.B. \& Downs, R.J. 1979. Bromelioideae. In: Flora Neotropica, Hafner Press, New York, pp. 1493-2142.

Sousa, G.M. \& Wanderley, M.G.L. 2000. Aechmea Ruiz $\&$ Pav. (Bromeliaceae) do estado de Pernambuco, Brasil. Acta Botanica Brasilica 14: 77-97.

Souza, V.C. \& Lorenzi, H. 2012. Botânica Sistemática: guia ilustrado para identificação das famílias de fanerógamas nativas e exóticas no Brasil, baseado em APG III, $3^{\text {a }}$ edição. Instituto Plantarum, Nova Odessa.

Thiers, B. 2014. Index Herbariorum: A global directory of public herbaria and associated staff. New York Botanical Garden's Virtual Herbarium. Available at: http://sweetgum.nybg.org/ih/ (access in 25-IV-2014).

Tölke, E.E.A.D., Silva, J.B., Pereira, A.R.L. \& Melo, J.I.M. 2011. Flora vascular de um inselbergue no estado da Paraíba, Nordeste do Brasil. Revista Biotemas 24: 39-48.

W $^{3}$ Tropicos. Missouri Botanical Garden. 2014. Available at: http://www.tropicos.org/Name/23524308 (access in 25-IV-2014). 